NBER WORKING PAPER SERIES

\title{
THE MACROECONOMIC EFFECTS OF MACROPRUDENTIAL POLICY: EVIDENCE FROM A NARRATIVE APPROACH
}

\author{
Diego Rojas \\ Carlos A. Vegh \\ Guillermo Vuletin \\ Working Paper 27687 \\ http://www.nber.org/papers/w27687 \\ NATIONAL BUREAU OF ECONOMIC RESEARCH \\ 1050 Massachusetts Avenue \\ Cambridge, MA 02138 \\ August 2020
}

We would like to thank Larry Ball, Tito Cordella, Robert Dekle, Sebastian Edwards, Alain Ize, Graciela Kaminsky, Sebnem Kalemli-Ozcan, Nicolas Magud, Hashem Pesaran, Alessandro Rebucci, Daniel Riera-Crichton, Augusto de la Torre, Bent Vale, Jaume Ventura, and seminar/ conference participants at USC, Norges Bank, NBER/Central Bank of Turkey, IMF, Central Bank of Uruguay, FLAR conference (Cartagena), and Central Bank of Bolivia for useful and insightful comments. Jorge Puig, Becky Newman, and Pedro Pablo Matinez provided excellent research assistance. The views expressed in the paper are the authors' own and do not necessarily reflect those of the World Bank. The views expressed herein are those of the authors and do not necessarily reflect the views of the National Bureau of Economic Research.

NBER working papers are circulated for discussion and comment purposes. They have not been peer-reviewed or been subject to the review by the NBER Board of Directors that accompanies official NBER publications.

(C) 2020 by Diego Rojas, Carlos A. Vegh, and Guillermo Vuletin. All rights reserved. Short sections of text, not to exceed two paragraphs, may be quoted without explicit permission provided that full credit, including $\odot$ notice, is given to the source. 
The Macroeconomic Effects of Macroprudential Policy: Evidence from a Narrative Approach Diego Rojas, Carlos A. Vegh, and Guillermo Vuletin

NBER Working Paper No. 27687

August 2020

JEL No. E32,E52,E58,F31,F41

\begin{abstract}
We analyze the macroeconomic effects of macroprudential policy - in the form of legal reserve requirements - in three Latin American countries (Argentina, Brazil, and Uruguay). To correctly identify innovations in changes in legal reserve requirements, we develop a narrative approach based on contemporaneous reports from the IMF and Central Banks in the spirit of Romer and Romer (2010) - that classifies each change into endogenous or exogenous to the business cycle. We show that this distinction is critical in understanding the macroeconomic effects of reserve requirements. In particular, we show that output falls in response to exogenous increases in legal reserve requirements but would seem not to be affected (or could even increase!) when using all changes and relying on traditional time-identifying strategies. This bias reflects the practical relevance of the misidentification of endogenous countercyclical changes in reserve requirements. We also push the empirical frontier along two important dimensions. First, in measuring legal reserve requirements, we take into account both the different types of legal reserve requirements in terms of maturity and currency of denomination as well as the structure of deposits. Second, since in practice reserve requirement policy is tightly linked to monetary policy, we also jointly analyze the macroeconomic effects of changes in central bank interest rates. To properly identify exogenous central bank interest rate shocks, we follow Romer and Romer (2004).

Diego Rojas

The World Bank

1818 H Street, NW

Washington, DC 20433

United States

lrojasalvarado@worldbank.org

Carlos A. Vegh

School of Advanced International Studies (SAIS)

Johns Hopkins University

1717 Massachusetts Avenue, NW

Washington, DC 20036

and NBER

cvegh1@jhu.edu

\author{
Guillermo Vuletin \\ The World Bank \\ 1818 H Street NW \\ Washington, DC 20433 \\ gvuletin@worldbank.org
}




\section{Introduction}

The Global Financial Crisis triggered an intense debate on the pros and cons of using macroprudential policy, broadly defined as the use of prudential tools, such as reserve or capital requirements, to deal with systemic risk, credit/financial cycle, and macroeconomic stabilization purposes. Although the discussion is certainly not novel - many emerging countries had resorted to macroprudential policy well before Lehman Brothers' demise on September 15, 2008 - it took an urgent undertone in light of the sudden realization of the severe contractionary forces that could be unleashed by the abrupt unwinding of financial imbalances and systemic risk. Perhaps one of the best examples of the renewed debate on macroprudential policy is the resurgence of the so-called "Tobin tax" - a financial tax on short-term capital inflows - whose popularity had arguably reached a low point by the mid-2000's, after gaining some limited popularity in previous decades thanks to its use by Chile. ${ }^{1}$ The mere fact that even the IMF - presumably a bulwark of macroeconomic orthodoxy - has come out in favor of using Tobin taxes under some circumstances is a dramatic illustration of the search for new macroprudential policy tools in the post-Lehman world (see Ostry et al., 2010).

While there is a blossoming theoretical literature (e.g., Korinek, 2011; Bianchi and Mendoza, 2012 and 2018; Bianchi, Lui, and Mendoza, 2016; Mendoza, 2016; Jiménez et al., 2017; Cizel et al., 2019; Meeks, 2017; Aikman et al., 2019), the empirical evidence on the determinants and effects of macroprudential policy has been rather limited, mainly because of the absence of readily-available panel datasets on macroprudential tools for long spans of time and the lack of sound identification strategies. In fact, many studies rely on SVAR-type, time-identification assumptions which, as will be shown later in this paper, constitute a very poor identification strategy. The empirical literature has generally focused on understanding the relationship between macroprudential and monetary policy in response to external shocks as well as assessing the effectiveness of macroprudential policy. ${ }^{2}$

Most existing empirical studies, however, focus on a small set of countries (e.g., Vargas Herrara, Varela, Betancourt, Rodriguez, 2010; Izquierdo, Loo-Kung, and Rojas-Suarez, 2013)

\footnotetext{
${ }^{1}$ See De Gregorio, Edwards, and Valdes (2000).

${ }^{2}$ See also Borio and Shim (2007), Vargas Herrara, Varela, Betancourt, and Rodriguez (2010), Calderon and Serven (2014), IMF (2011), Ma, Xiandong, and Xi (2013), Montoro and Moreno (2011), De la Torre, Ize, and Schmukler (2012), Powell (2012, Chapter 6), Glocker and Towbin (2012), and Federico, Vegh, and Vuletin (2014).
} 
and/or a limited sample period (Gray 2011; Claessens and Ghosh, 2012). Some exceptions include, for example, Federico, Vegh, and Vuletin (2014) who show - using a quarterly legal reserve requirement dataset for 52 countries dating back as early as 1970 - that macroprudential policies are much more frequently changed in developing and emerging economies (on average, once every 2 years) than in industrial countries (on average, once every 12 years). In particular, they show that in developing and emerging economies, this frequent change in macroprudential policy follows a countercyclical behavior (i.e., central banks reduce reserve requirements during episodes of capital outflows and output contractions), typically acting as a substitute of monetary policy which, unlike industrial countries, is often procyclical (i.e., increasing central bank interest rates during episodes of capital outflows and output contractions). ${ }^{3,4}$ In other words, during bad times for example, when capital is flowing out and credibility is at a low point, while monetary policy is used in a procyclical manner in order to defend the currency and fight inflationary pressures, macroprudential policy provides a second instrument which is used for macroeconomic stabilization purposes. ${ }^{5,6}$ In fact, Figure 1 provides evidence of this type of rationale by focusing on terms of trade shocks. To fix ideas, a negative terms of trade shock (whose effects follow from just inverting the signs of the impacts shown in Figure 1), reduces output (Panel A), depreciates the currency (Panel B), pushes inflation higher (Panel C), and induces the central bank to raise policy rates (Panel

\footnotetext{
${ }^{3}$ Monetary policy procyclicality occurs because many exchange rate depreciations episodes, especially in Latin America and other financially vulnerable developing and emerging countries, are triggered by sudden capital outflows which put pressure on the exchange rate typically triggering currency crisis/large depreciations and banking crisis due to the presence of liability dollarization and balance sheet currency mismatches and output contractions. This is indeed the reason why central banks, during bad times of capital outflows and output falls, usually attempt to defend the currency by increasing the central bank interest rate. By the same token, during good times, central banks are reluctant to increase central bank interest rates for fear of attracting even more capital inflows. See Vegh and Vuletin (2012) for details about this policy dilemma.

${ }^{4}$ In fact, this has been part of the standard IMF policy advice to developing countries, most notably during the Asian crisis of 1997. To quote Stanley Fischer, at the time the IMF's First Deputy Managing Director, in a 1998 lecture delivered at UCLA, "[i]n weighing this question [are the IMF programs in Asia too tough?], it is important to recall that when they approached the IMF, the reserves of Thailand and Korea were perilously low, and the Indonesian rupiah was excessively depreciated. Thus, the first order of business was, and still is, to restore confidence in the currency. To achieve this, countries have to make it more attractive to hold domestic currency, which, in turn, requires increasing interest rates temporarily, even if higher interest costs complicate the situation of weak banks and corporations."

${ }^{5}$ This was, for example, the position of the Turkish Central Bank as described in a Financial Times article on December 13th, 2010. The deputy governor argued that the way to deal with heavy capital inflows was to decrease interest rates (to reduce capital inflows and currency appreciation) while using other instruments (i.e., reserve requirements) to reduce credit growth.

${ }^{6}$ Naturally, in order for macroprudential policy to provide an effective second instrument, one would need to assume some imperfect substitutability between foreign and domestic assets (in order to create a wedge where a second instrument can operate), along the lines of Lahiri and Vegh (2003).
} 
D) and cut legal reserve requirements in the short-run (Panel E).

\section{INSERT FIGURE 1}

When focusing on the effects of macroprudential policy, most studies typically analyze the impact on domestic credit conditions (e.g., Montoro and Moreno, 2011; Terrier et al., 2011; Crowe, Dell'Ariccia, Igan, and Rabanal, 2013; Lim et al., 2011; Tovar, Garcia-Escribano, and Vera Martin, 2012) and economic activity (e.g. Glocker and Towbin, 2012). However, the effectiveness of macroprudential policy as a macroeconomic stabilizing tool is still very much an open question.

The purpose of this paper is to contribute to the empirical literature on the macroeconomic effects of macroprudential policy, by focusing on legal reserve requirements (RR, hereafter). The focus on $R R$ is only natural for three main reasons: (i) RR are arguably the most common macroprudential tool (Federico, Vegh, and Vuletin, 2014), (ii) collecting time series data on RR is, in principle, "easier" than collecting data on other prudential tools such as capital requirements (especially for long time spans), (iii) as is the case when using cyclicallyadjusted revenue measures to assess changes in tax policy (e.g., Romer and Romer, 2010; Vegh and Vuletin, 2015; and Riera-Crichton, Vegh, and Vuletin, 2016), total banks' reserves (calculated as the ratio of banks deposits at the central bank to bank deposits) are not valid proxies for changes in policy instruments such as RR (Federico, Vegh, and Vuletin, 2014). ${ }^{7}$

In particular, we push the empirical frontier on several crucial dimensions. First, in terms of measuring RR, while building upon existing data from Federico, Vegh, and Vuletin (2014) that accounts for the different types of RR in terms of maturity and currency denomination, we now construct a novel metric of effective $R R$ which also takes into account the structure of deposits. Second, in terms of the identification of exogenous RR shocks, we develop a Romer and Romer (2010) type of narrative for the nature of RR changes. In fact, we show that misidentification problems are at the core of some counterintuitive results in the existing literature (for instance, the finding that an increase in RR increases private credit growth). ${ }^{8}$

\footnotetext{
${ }^{7}$ For example, as will be discussed later in the paper, while total banks' reserves may fluctuate due to non-policy factors (including the structure of deposits), RR changes due to central bank policy take place, on average, every 2 years in developing and emerging markets.

${ }^{8}$ See, for example, Figure 10 (bottom-right impulse response) in Tovar, Garcia-Escribano, and Vera-Martin (2012).
} 
When shocks to RR are properly identified as exogenous to the business cycle by using a narrative approach, we show that results change dramatically. In other words, we use changes in RR exogenous to the business cycle to analyze their macroeconomic effects, as opposed to those RR changes associated with the policy reaction function of the monetary authority to current or prospective output fluctuations. This is the quintessential problem of reverse causality. Third, as discussed before, since it proves impractical to analyze macroprudential policy in isolation, we also jointly analyze the macroeconomic effects of the central bank policy interest rate (IR, hereafter) on the macroeconomy. To properly identify exogenous IR shocks, we follow Romer and Romer's (2004) approach and purge the policy rate from systematic responses to information about future economic developments. Given the time-consuming efforts needed to carry out the analysis along these several critical dimensions, we focus our analysis on three Latin American countries (Argentina, Brazil, and Uruguay) since the early 1990s.

The paper proceeds as follows. Section 2 describes the novel RR dataset and some broad features of the data. Section 3 shows empirical evidence on the macroeconomic effects of macroprudential and monetary policies relying on traditional time-identifying assumptions. In line with the predictions of any standard macro model, we find a negative effect of central bank interest rate changes on output. Interestingly, we find a puzzling finding regarding the effect of macroprudential policy on economic activity: macroprudential policy does not have (or could even have a positive) effect on economic activity. A positive effect would imply that an increase in reserve requirements leads to an increase in output and a cut in reserve requirements makes output fall. We then turn to our new identifying strategy. To the best of our knowledge, this is the first instance in this macroprudential literature in which such a narrative approach has been used. Section 4 discusses the narrative analysis and classifies the motivation for each RR change. Using historical documents, including IMF and central banks reports, we classify changes in RR into (i) endogenous changes, which were mainly motivated by current or prospective output fluctuations (i.e., when output growth differs from normal) and (ii) exogenous changes, which were triggered by reasons exogenous to the business cycle, including microprudential factors and financial liberalization. As discussed before, since it proves impractical to analyze macroprudential policy without considering the role of monetary policy, Section 5 extends the analysis to identify exogenous IR shocks following Romer and 
Romer's (2004) approach. With our new measures of exogenous RR and IR shocks in hand, Section 6 examines their effects on output and also on market interest rate spreads (to have a sense of the transmission mechanism). We show that refining the identification method proves to be critical to correctly assessing the output effects of changes in reserve requirements. In particular, when properly identified, the effect of reserve requirements on economic activity is negative. That is to say, an increase in reserve requirements leads to a fall in output and a cut in reserve requirements makes output increase. We show that the countercyclical nature of endogenous changes in reserve requirements is at the heart of this bias. Section 7 offers some concluding remarks.

\section{Reserve requirement data}

Our starting point is the quarterly RR database built by Federico, Vegh, and Vuletin (2014) which identifies different types of RR in terms of maturity and currency of denomination. ${ }^{9}$ Based on this, we construct a metric of effective RR that also takes into account the structure of deposits for each of the three countries included in this paper (Argentina, Brazil, and Uruguay). ${ }^{10}$ As shown in Table 1, Panel A, we identify a total of 93 quarterly changes in RR. Specifically, Argentina, Brazil, and Uruguay changed RR on 49, 31, and 13 occasions, respectively. In other words, Argentina, Brazil, and Uruguay changed their RR, on average, about once every 7, 9, and 26 months, respectively.

To set the stage, we begin by briefly discussing some broad features of the data; in particular the varieties of RR (Section 2.1), long- and short-run properties (Section 2.2), and the variable effectively used to conduct the empirical analysis (Section 2.3). ${ }^{11}$

\section{INSERT TABLE 1}

\footnotetext{
${ }^{9}$ The current version of this database comprises 66 countries, 15 industrial and 51 developing (see Federico, Vegh, and Vuletin, 2014, for details) and is available at www.guillermovuletin.com.

${ }^{10}$ The analysis covers the period 1990:1-2018:1 for Argentina, 1994:3-2018:2 for Brazil, and 1990:1-2018:2 for Uruguay. This dataset is also available from www.guillermovuletin.com.

${ }^{11}$ Our study also uses other macroeconomic variables such as real GDP, inflation, central bank interest rates, market interest rates, and exchange rates, all of them at the quarterly frequency. Most of these data were gathered from IFS (IMF) and local sources. See Appendix 8 for a description of data and sources.
} 


\subsection{Varieties of legal reserve requirements}

Figure 2 illustrates the varieties of $R R$ in our sample: (i) RR that vary according to maturity (the case of Brazil) and (ii) RR that vary according to both maturity and currency of denomination (the cases of Argentina and Uruguay). The existence of RR based on currency of denomination in many developing countries should perhaps come as no surprise given the widespread phenomenon of "dollarization" or, more broadly, foreign currency deposits. As a general rule, short-term deposits (i.e., demand deposits) as well as foreign currency deposits are typically associated with higher RR than longer-term local-currency based deposits. For example, the historical average $\mathrm{RR}$ on demand deposits in Brazil has been 53 percent compared to about 19 and 17 percent for savings and term deposits, respectively. This differential RR structure has been aimed at, naturally, guaranteeing more liquidity in banks for shortterm deposits. Regarding currency denomination, in Uruguay, for example, the average RR for deposits in local currency has been 9 percent compared to about 15 percent for foreign currency deposits. This differential reflects concerns with sudden reversals in foreign currency flows (Quizpe and Rossini, 2010) that may spell trouble for the banking sector due to currency mismatches in banks' balance sheets (Reinhart, Rogoff, and Savastano, 2003).

\section{INSERT FIGURE 2}

\subsection{Long- and short-run properties of legal reserve requirements}

To get an idea of how RR have evolved over time, Figure 3 plots the simple average and

standard deviation of RR for each country. With the exception of Uruguay which, compared to other developing countries, has been relatively open from a financial point of view, Argentina and Brazil show a declining trend in their average RR, reflecting financial liberalization and financial deepening. The average $\mathrm{RR}$ has decreased in Argentina and Brazil from values close to 30 and 50 percent in the mid-1990s to 19 and 26 percent in 2018, respectively. We also see an increase in average RR in the period 2005-2010 reflecting the greater reliance on macroprudential policy in the period surrounding Lehman's fall on September 15, 2008. Another general feature - particularly in Argentina and Brazil - has been an important reduction in the dispersion of $\mathrm{RR}$ associated with different types of deposits. For example, 
while in $1995 \mathrm{RR}$ in Brazil ranged from 90 percent on demand deposits to 27 percent on term ones, the range had narrowed to between 40 and 34 percent in 2018.

\section{INSERT FIGURE 3}

How synchronized are changes in different types of RR? Figure 4 shows the change in $\mathrm{RR}$ for each country. While the levels of RR tend to vary across different categories of deposits (Figure 2), their changes appear to be positively related (Figure 4). Indeed, in virtually all cases we cannot reject the null hypothesis that such correlations are positive and statistically significant (Table 2). Naturally, this high degree of synchronicity and positive association in changes in $\mathrm{RR}$ implies that changes in the simple average of $\mathrm{RR}$ is highly related to simultaneous changes in RR for different type of categories of deposits (Table 2).

INSERT FIGURE 4 AND TABLE 2

\subsection{Effective legal reserve requirement}

While central bank's macroprudential policy tools involve the selection of RR for different type of categories of deposits (for example, their maturity and currency of denomination), a proper metric to evaluate its impact on the macroeconomy should also consider the structure of deposits. Much like the average marginal income tax rate measure on the income tax front (e.g., Romer and Romer, 2010), an effective RR measure should weigh the RR for each different type of category of deposits based on the importance of each type of deposit as a proportion of total deposits in the system:

$$
\begin{aligned}
\text { effective } R R_{t} & =\sum_{i} R R_{i t} \omega_{i t}, \quad i=1, \ldots, N \\
\omega_{i t} & \equiv \frac{\text { Deposit }_{i t}}{\text { Total deposits }},
\end{aligned}
$$

where $i$ is the category of maturity and currency (e.g., demand deposits in local currency) and $t$ is the time (defined by year and quarter). Since such effective $R R$ measure could change over time due to changes in $\mathrm{RR}$ (i.e., $\Delta R R_{i t}$ ) and/or may also fluctuate due to changes in non-policy factors such as changes in the structure of deposits (i.e., $\Delta \omega_{i t}$ ), we propose to use 
an effective measure of $\mathrm{RR}$ with constant weights based on the historical average structure of deposits for the empirical analysis regarding the macroeconomic effects of macroprudential policy:

$$
\text { effective constant } \begin{aligned}
R R_{t} & =\sum_{i} R R_{i t} \times \bar{\omega}_{i}, & i=1, \ldots, N \\
\bar{\omega}_{i} & \equiv \frac{1}{T} \sum_{t} \frac{\text { Deposit }_{i t}}{\text { Total deposits }} & t=1, \ldots, T
\end{aligned}
$$

Figure 5 shows the change in this new measure for each country. Interestingly, Table 2 also shows that the correlation between effective $R R$ (ERR, hereafter) and effective constant $R R$ (ECRR, hereafter) is extremely high for all countries analyzed pointing that, in practice, most of the sources of changes in ERR is due to changes in RR as opposed to changes in the structure of deposits.

Moreover, it is worth noting, that changes in ERR and ECRR are highly related with changes in total banks' reserves calculated as the ratio of banks' deposits at the central bank to banks' deposits (which includes both mandatory and voluntary banks' reserves). For Argentina, Brazil, and Uruguay the correlation coefficients between exogenous changes in ECRR and changes in total banks' reserves are 0.31, 0.68, and 0.99, respectively (statistically significant at the one percent level in all cases). This suggests that exogenous ECRR changes are important determinants of changes in total banks' reserves.

\section{INSERT FIGURE 5}

\section{Evidence from traditional identification strategy}

Before turning to the new identifying strategy, this section relies on the traditional time identifying strategy used in the monetary policy literature (Leeper, Sims, and Zha, 1996; Bernanke, Gertler, and Watson, 1997; Christiano, Eichenbaum, and Evans; 1999; Bernanke, Boivin, and Eliasz, 2005) which assumes that central bank interest rate innovations have no contemporaneous effects on output. ${ }^{12}$ We estimate the effects of monetary and macroprudential policies

\footnotetext{
${ }^{12}$ See Coibion (2012) for an excellent review and a discussion of the limitations of this approach for the case of the United States.
} 
on economic growth using quarterly data and the following Panel VAR: ${ }^{13}$

$$
\Delta Y_{i, t}=\alpha_{i}+A(l) \Delta Y_{i, t-1}+\mu_{i, t}
$$

where subscripts $i$ and $t$ denote country and time, respectively, $\alpha_{i}$ is the country fixed effect, $\Delta Y$ denotes the vector composed by the real GDP growth rate, inflation, $\triangle E C R R^{\text {all }}$ that captures the percentage point changes in effective constant legal reserve requirement, and $\Delta I R^{\text {all }}$ that represents the percentage point changes in the central bank interest rate, and $\mu$ is the error term. ${ }^{14,15}$ It is important to note that for now (i.e., when evaluating the evidence from traditional identification strategy), all changes in ECRR and IR are used to identify macroprudential and monetary shocks (as opposed to exogenous ones). Notice that, by construction, specification (1) does not allow $\Delta E C R R^{\text {all }}$ and $\Delta I R^{\text {all }}$ to affect real GDP growth rate contemporaneously, but rather with a one quarter lag. Figure 6 shows our findings. We find a negative effect of IR on economic activity (Panel B). In particular, a one percentagepoint increase in IR reduces output up by $-0.10(s e=0.03)$ percent after a year of the shock. Interestingly, we find a puzzling finding (i.e., contrary to the predictions of any standard macro model) regarding the effect of $\mathrm{RR}$ on economic activity (Panel A): increases in reserve requirements do not have a negative effect on economic activity (the effect ranges from weakly positive to neutral).

\section{INSERT FIGURE 6}

What if changes in macroprudential and monetary policies were allowed to affect economic activity within the same quarter? We now estimate the effects of monetary and macroprudential policies on economic growth using the single-equation approach proposed by Jordà

\footnotetext{
${ }^{13}$ While the empirical monetary literature in the United States and other industrial countries has mostly relied on the use of monthly data (typically using industrial production as a proxy for economic activity), this is not the dominant approach when focusing on developing countries (e.g., Disyatat and Vongsinsirikul, 2003; Le, 2009). First, for many developing countries monthly industrial production is unavailable or available only very recently. For example, while Argentinean monthly industrial production is available at best since early 2000s, quarterly real GDP is available since 1990. Even when available, the quality and/or relevance of industrial production monthly data, in particular as a proxy for economic activity, is doubtful. For example, while both quarterly and annual data indicate that Argentina grew 4.1 percent in 2008, monthly data suggest a drastic fall of 12.7 percent.

${ }^{14}$ For the IR we use the monetary policy rate published by the central bank in the case of Argentina, the SELIC rate in the case of Brazil, and the money market rate in the case of Uruguay. See Appendix 8 for details.

${ }^{15}$ We use four lags. Our results for the case of eight lags remain almost the same as in the four-quarter specification. Figures showing the effects for the eight-lag estimations are not shown for the sake of brevity.
} 
(2005) and Stock and Watson (2007), which is based on linear "local projections" (LP). The use of LP provides several advantages over the traditional SVAR methodology pioneered by Blanchard-Perotti (2002). Specifically, LP can be estimated by single-regression techniques (least-squares dummy variables, LSDV, in our case) and are more robust to potential misspecifications. The cumulative response of output growth at the horizon $h$ is estimated based on the following regression:

$$
\begin{aligned}
\Delta y_{i, t+h}= & \alpha_{i, h}+\beta_{h} \Delta E C R R_{i, t}^{\text {all }}+\delta_{h} \Delta I R_{i, t}^{\text {all }}+\sum_{l=1}^{4}\left(\psi_{l, h} \Delta E C R R_{i, t-l}^{\text {all }}+\theta_{l, h} \Delta I R_{i, t-l}^{\text {all }}\right)+ \\
& +\sum_{l=1}^{4}\left(\lambda_{l, h} \Delta y_{i, t-l}+\phi_{l, h} \pi_{i, t-l}\right)+\sum_{l=0}^{h-1}\left(\omega_{l h} \Delta E C R R_{i, t+h-l}^{\text {all }}+\nu_{l h} \Delta I R_{i, t+h-l}^{\text {all }}\right)+ \\
& +\mu_{i, t, h},
\end{aligned}
$$

Unlike VAR or SVAR specifications, the estimated coefficients contained in the polynomial lags associated with $\psi_{h}$ and $\theta_{h}$ are not used directly to build the impulse response function (IRF) values but only serve as controls, "cleaning" the $\beta_{h}$ and $\delta_{h}$ coefficients from the dynamic effects of output and inflation and the effects of past changes in ECRR and IR. It is important to note that, in this LP approach, each step in the cumulative IRF is obtained from a different individual equation. Defining $\Delta y_{i, t+h}$ as the accumulated output growth from $t-1$ to $t+h$ (i.e., $\Delta y_{i, t+h} \equiv y_{i, t+h}-y_{i, t-1}$ ), the cumulative IRF values are obtained directly from $\beta_{h}$ and $\delta_{h}$ estimated coefficients at each time horizon $h$. Therefore, each coefficient $\beta_{h}$ and $\delta_{h}$ represents the step in the cumulative IRF at a forward time $h$ and is read as the accumulated response of output growth to a one percentage point increase in the effective constant in reserve requirement or central bank interest rate, respectively. In order to correct for the potential bias in the local projections estimator when ignoring shocks occurring between periods $t+1$ and $h$ (see Teulings and Zubanov, 2014), we add a vector of leads of our main shocks.

Note that now, unlike specification (1), contemporaneous changes in effective constant reserve requirement and central bank interest rate are allowed to affect economic activity. Notice that the second and third terms on the right hand side of the equation in specification (2) have a $t$ subindex; unlike in specification (1) which have a $t-1$ subindex. Figure 7 shows our findings. While we still find a negative effect of IR on economic activity (Panel B), even on impact, we still find no effect of RR on economic activity (Panel A). In sum, so far, we 
seem to find robust evidence that, based on a traditional identification strategy, monetary police has a negative effect on output, yet macroprudential policy does not have a negative effect on economic activity.

\section{INSERT FIGURE 7}

\section{New measure of reserve requirement shock}

This section presents a new narrative-based measure of reserve requirement changes à la Romer and Romer (2010). Subsection 4.1 presents the criteria and sources to identify the motivation for each RR change. Armed with this classification scheme, Subsection 4.2 presents the new measure of $\mathrm{RR}$ shocks resulting from applying the criteria.

\subsection{Sources and identifying motivation}

The sources of the narrative analysis are primary documents issued by policymakers both at international and country institutions at the time. Our key sources are IMF reports including Staff Reports and Recent Economic Developments, as well as central banks' documents including working papers and monetary and financial stability reports, among others. Following Romer and Romer's (2010) identification strategy, changes in RR are differentiated between those that were mainly motivated by current or projected fluctuations in output, which we will call endogenous, from those that were triggered by other reasons, which we will call exogenous. In the rest of this subsection, we present our categorization strategy and also provide, as examples, shorter versions of some of the narratives which are fully developed in the Online Appendix.

Endogenous changes in reserve requirements are ones typically taken to offset developments that would cause output growth to differ from trend. This includes macroprudential cases where policymakers were intentionally responding to current or projected economic activity, including those events related to fluctuations in capital flows. What follows is a brief description of two episodes of changes in RR that took place in Argentina. They involved an increase in RR in 1993 (during the Convertibility Plan euphoria) and a series of decreases in RR in 1995 (right after the Tequila crisis) and are categorized as endogenous (good times) and endogenous (bad times), respectively. 
Endogenous (good times): In the third quarter of 1993, RR decreased on all deposits by 3 percentage points. The strong economic upswing that followed the adoption of the Convertibility Plan in March 1991 continued at a more moderate pace in 1993, as real GDP rose by about 6 percent and consumer price inflation declined to 7.4 percent (from 18 percent in the previous year). A high real interest rate continued attracting capital inflows, which exceeded the external current account deficit by a large margin and gross international reserves increased by more than US $\$ 4$ billion to over US $\$ 15$ billion by the end of 1993 . As a consequence, the peso appreciated 5.5 percent, and merchandise imports grew by 13 percent whereas exports rose by some 7 percent. Two important factors added to this situation of economic growth with low inflation and trade and current account deficits: the privatization of the state oil company (YPF), which raised about U\$S 2 billon from abroad, and the floating of over U\$S1 billion of government bonds in December of 1993. On the fiscal side, excluding privatization proceeds, the economy registered a primary fiscal surplus of 1.8 percent of GDP. As to monetary policy, it was expansive as broad money rose at an annualized rate of 50 percent. Reserve holdings as a ratio of total deposits had remained at about 22 percent since 1992, in part due to the restructuring of reserve requirements in February 1993. This restructuring lowered the average requirement, and was offset by a 3 percentage point increase in all reserve requirements in mid-August 1993 designed to sterilize part of the capital inflow from the sale of YPF. This increased in RR is categorized as endogenous (good times).

Endogenous (bad times): The four years of rapid economic growth aided by large private capital inflows were interrupted in the first few months of 1995, when the Mexican crisis triggered an outflow of capital from Argentina that in turn precipitated a sharp contraction in domestic demand and activity. The capital outflow was reflected in a decline of almost US\$8 billion in deposits in the Argentine banking system (or around 18 percent of total deposits) between late December 1994 and mid-May 1995, a sharp decline in the stock and bond markets, and a surge in interest rates. The financial crisis in the first half of 1995 weakened the financial system. The Central Bank responded to these events by lowering reserve requirements on several occasions during 1995 in order to strengthen the banking system's liquidity position and promote lower interest spreads.

Exogenous changes in reserve requirements are those not taken to offset factors pushing growth away from normal. We group these changes under 3 categories: financial liberaliza- 
tion, microprudential purposes, and liquidity regulation. The quintessential exogenous change might be because of financial liberalization arguments; a reduction in RR motivated by a belief that lower RR will increase private credit and output in the long run. Such an action is completely different from the stabilization measures discussed above because the goal is to raise normal growth, not to offset shocks acting to reduce growth relative to normal. For example, in early 1990s, Argentina gradually reduced their RR from 79 percent in 1992 to about 40 percent in early 1993. In those years, the authorities continued their efforts to bring about a transformation of the structures and institutions of the economy, moving away from decades of overregulation and state intervention and toward a flexible, dynamic, and open economy based on private initiative.

On other occasions, central banks change RR for microprudential regulation purposes including measures aiming at improving financial intermediation as well as guarantying the solvency of the financial system. For example, while the financial markets in Uruguay are closely linked to international markets, the financial system continued in early 1991 to be characterized by a wide spread between lending and deposit rates in domestic currency. In the third quarter of 1991, the Central Bank of Uruguay reduced the RR on local currency demand and savings deposits by 2 percentage-points to narrow this spread and facilitate financial intermediation.

Another reason not associated to actions aiming at stabilizing output is related to the use of RR for liquidity regulation purposes. In these occasions, central banks change RR to affect market's liquidity needs in an effort to ease pressure on inflation, exchange rate, and interest rate. For example, in March of 1999, the Central Bank of Brazil increased the $\mathrm{RR}$ on term deposits from 20 percent to 30 percent. The international confidence crisis of 1997 and 1998 as a consequence of the financial problems faced by Russia and Asia, jointly with an increased concern about debt sustainability led to strong capital outflows in Brazil, culminating in the floating of the exchange rate in January 1999, which was a year of stagnant output growth and flat or contracting domestic demand. At that time, a new policy framework was then envisaged to keep inflation under control without further compromising the fiscal accounts. To attain this objective, the authorities implemented in the first quarter of 1999 different measures of monetary policy which included changes in RR. In particular RR on term deposits were raised from 20 percent to 26.5 percent starting on March 5th 1999, and 
to 30 percent beginning on March 12th 1999.

\subsection{Applying the criteria}

Panel A in Table 1 shows that out of the total 93 quarterly RR changes, our narrative analysis identifies 62 as exogenous and 31 as endogenous. Panel B shows that less than half of exogenous changes (28 out of 62 ) are associated with microprudential arguments. The remaining 34 exogenous cases are splitted between financial liberalization (14) and liquidity regulation (20). Panel $\mathrm{C}$ shows that almost 60 percent of endogenous changes (or 18 out of 31) are associated with bad times and the remaining cases with good times.

Figure 8 shows endogenous and exogenous changes in the ECRR measure for each country, as well as the composition of endogenous changes into those associated to measures aiming at offsetting output fluctuations in good and bad times. Macroprudential use of RR (i.e., en-

dogenous changes) has been common across the board in our three Latin American economies in the period surrounding the 2008 global crisis. Interestingly, yet not surprisingly, the use of RR for macroprudential (i.e., output stabilization) purposes has not been, by any means, a recent phenomenon as some of the latest papers in the literature seem to suggest. Changes in RR have been frequently used for countercyclical purposes in the past. For example, central banks of Argentina and Brazil actively used them before and after the financial crisis of 1995. Argentina also reduced the RR on several occasions in 2001 in an attempt to stimulate economic activity after several quarters of negative output growth.

\section{INSERT FIGURE 8}

\section{New measure of central bank interest rate shock}

The exogenous shock to the interest rate is calculated using, in spirit, the strategy proposed by Romer and Romer (2004) and based on data from the World Economic Outlook (WEO) historical forecast data. This dataset contains 2-years of historical data and 6-years of forecast data, for three variables: GDP growth, inflation, and the current account balance as percent of GDP. The 6-years of forecast data are presented twice every year once in Spring and once in the Fall. For instance, in 1991 there are historical data for 1989 and 1990 as well as 
the forecast data for the years 1991-1996 that were projected in the Spring as well as the projections done in the Fall for the same years. ${ }^{16}$

The Spring forecast of inflation and GDP growth is used as the forecast for the second and third quarters while the Fall forecast is taken as the forecast for the fourth and first quarter. In the spirit of Romer and Romer (2004), for each country, the change in the policy rate is regressed on two lags of inflation, GDP growth, the policy rate, and on (4 quarters) forecasted values for inflation, the growth rate as well as changes in lags and in forecasted values of these variables. The residuals from this regression represent the exogenous shocks to the policy rate (i.e., $\left.\Delta I R^{e x o g}\right)$. In particular, for each country, we run the regression

$$
\triangle I R_{t}=\theta_{0}+\theta_{1} I R_{t-1}+\theta_{2} I R_{t-2}+\sum_{k=-2}^{4}\left(\omega_{k} \pi_{t+k}+\delta_{k} D \pi_{t+k}+\beta_{k} \triangle y_{t+k}+\gamma_{k} D \triangle y_{t+k}\right)+\mu_{t}
$$

where $\pi$ represents inflation and $D X_{t+k}=X_{t+k}-X_{t+k-2}$ for variable $X .{ }^{17}$ The residuals from the above regression are used as our policy rate shock. This shock purges the policy rate from systematic responses to information about future developments. In other words, these residuals show changes in the policy rate that are not taken in response to information about future economic developments. Figure 9 shows the findings for each country.

\section{INSERT FIGURE 9}

\section{Evidence from new identification strategy}

Armed with our new measures of exogenous macroprudential shocks (Section 4) and monetary shocks (Section 5), we now re-examine the effects of these policies on economic activity. In other words, as part of a proper identification strategy, we solely use exogenous (to the business cycle) policy changes to evaluate the effect of policy changes on output and the transmission mechanism. The cumulative response of output growth at the horizon $h$ is estimated based

\footnotetext{
${ }^{16}$ The WEO historical data used in this paper corresponds to the April 17, 2018 update.

${ }^{17}$ Note that here we use the fact that only two forecasts (Spring and Fall) are available per year.
} 
on the following regression:

$$
\begin{aligned}
\Delta y_{i, t+h}= & \alpha_{i, h}+\beta_{h} \Delta E C R R_{i, t}^{\text {exog }}+\delta_{h} \Delta I R_{i, t}^{\text {exog }}+\sum_{l=1}^{4}\left(\psi_{l, h} \Delta E C R R_{i, t-l}^{\text {all }}+\theta_{l, h} \Delta I R_{i, t-l}^{\text {all }}\right)+ \\
& +\sum_{l=1}^{4}\left(\lambda_{l, h} \Delta y_{i, t-l}+\phi_{l, h} \pi_{i, t-l}\right)+\sum_{l=0}^{h-1}\left(\omega_{l h} \Delta E C R R_{i, t+h-l}^{\text {exog }}+\nu_{l h} \Delta I R_{i, t+h-l}^{\text {exog }}\right)+ \\
& +\mu_{i, t, h},
\end{aligned}
$$

where $\Delta E C R R^{\text {exog }}$ and $\Delta I R^{\text {exog }}$ represent the exogenous changes in effective constant legal reserve requirements and central bank interest rate. Notice that the only, yet critical, difference between this current specification (i.e., specification (4)) and specification (2) from Section 3 is the exogenous nature of macroprudential and monetary shocks now used. Panels $\mathrm{A}$ and $\mathrm{B}$ in Figure 10 show the findings of our new exogenous ECRR and IR series. Panel A shows that a one percentage-point increase in ECRR reduces output by $-0.12(s e=0.01)$ percent after a year. ${ }^{18}$ That is to say, we find a negative effect of RR on economic activity. These findings differ substantially from those obtained in Section 3 when using all ECRR changes and/or the timing identification strategy (Panels A in Figures 6 and 7). In those cases, changes in ECRR do not have a negative effect on economic activity. This striking difference shows in a very clear way the practical relevance regarding the strategy used to identifying policy innovations that are free of endogenous movements in ECRR. Panel B in Figure 10 shows, much more in line (qualitatively speaking) with Panel B in Figures 6 and 7 that increases in central bank interest rates induce a fall in output. Interestingly, compared to the traditional identification approach, properly identified central bank interest rate shocks have economically smaller effects on impact. In particular, while the effect after a year of a change in $I R^{e x o g}$ is $-0.12(s e=0.01)$ in Panel B in Figure 10, it is almost twice larger in absolute value, $-0.22(s e=0.07)$ when relying on $I R^{\text {all }}$ in Panel B in Figure $7 .{ }^{19}$ Panels $\mathrm{C}$ and $\mathrm{D}$ in Figure 10 shed some light regarding the transmission mechanism trough which

\footnotetext{
${ }^{18}$ To test that our findings are not driven by a single country's behavior, we estimated local projections excluding each country one-at-a-time. We find that a one percentage-point increase in RR reduces output in all regression estimates. For instance, if Brazil is excluded from the sample, output growth falls by 0.11 percent after a year. If Argentina or Uruguay are excluded, these figures are 0.13 and 0.12 respectively.

${ }^{19}$ We compare the findings from Figure 10 with those of Figure 7 , because in both cases we allow contemporaneous changes policy to affect economic activity which, in turn, enables us to contrast the impact effects.
} 
changes in ECRR and IR affect the economy. In line with the predictions of any standard macro model, increases in ECRR and IR increase the market interest rate spread (defined as lending minus deposit interest rates) especially in the short and long term, respectively.

\section{INSERT FIGURE 10}

\subsection{Biases due to misidentification}

Why is the effect of macroprudential policy on output negative when using properly identified exogenous changes and weakly positive or neutral when relying on the traditional approach? In the same vein, why is the effect of central bank interest rate policy on output less negative on impact when using properly identified exogenous monetary policy shocks than when relying on the traditional approach? In other words, what is the nature of the bias associated with the misidentification?

To illustrate this point, we now estimate the cumulative response of output growth at the horizon $h$ using the following regression:

$$
\begin{aligned}
\Delta y_{i, t+h}= & \alpha_{i, h}+\beta_{h} \Delta E C R R_{i, t}^{\text {endog }}+\delta_{h} \Delta I R_{i, t}^{\text {endog }}+\sum_{l=1}^{4}\left(\psi_{l, h} \Delta E C R R_{i, t-l}^{\text {all }}+\theta_{l, h} \Delta I R_{i, t-l}^{\text {all }}\right)+ \\
& +\sum_{l=1}^{4}\left(\lambda_{l, h} \Delta y_{i, t-l}+\phi_{l, h} \pi_{i, t-l}\right)+\sum_{l=0}^{h-1}\left(\omega_{l h} \Delta E C R R_{i, t+h-l}^{\text {endog }}+\nu_{l h} \Delta I R_{i, t+h-l}^{\text {endog }}\right)+ \\
& +\mu_{i, t, h},
\end{aligned}
$$

which is identical to specification (4) except that endogenous changes in ECRR and IR are used to identify the shock. Of course, by construction, this is a faulty strategy precisely because these policy changes are contaminated with endogeneity considerations. Yet we still use this approach solely with the purpose of illustrating the source of bias due to misidentification behind the traditional approach.

Figure 11 shows the findings. Panel A illustrates the fact that, relying on endogenous macroprudential policy, increases in ECRR seem to increase output. Naturally, this evidence goes against the evidence obtained based on exogenous changes and also from the one implied by any standard macro model. Panel B suggests that monetary policy tightening reduces output, which is in line with the evidence based on exogenous changes. 
How can we understand these changes considering that they are based on endogenous policy changes? This suggests that endogenous macroprudential policy changes, which are essentially countercyclical (i.e., RR decreases in bad times and increases in good times), if used to estimate the effect of macroprudential policy on output, will give the false impression that, for example, increases in ECRR are not that harmful for economic activity (Panels A in Figures 6 or 7 versus in Figure 10). In fact, this important source of bias due to misidentification would even suggest that increases in ECRR are expansionary for economic activity! That is to say, this bias on the macroprudential front will tend to underestimate the negative effects of changes in ECRR policy on output (much like we observe in Panel A in Figure 7). This countercyclical evidence of endogenous changes in RR is consistent with the example shown in the Introduction regarding the response of RR to a terms of trade shock (see Panel E in Figure 1) and also in line with the typical finding in developing countries from Federico, Vegh, and Vuletin (2014). In contrast, for central bank interest rate policy, the findings shown in Figure 11 suggest that endogenous changes in IR are essentially procyclical (i.e., IR increases in bad times). This procyclical evidence of endogenous changes in IR is consistent with the example shown in the Introduction regarding the response of IR to a terms of trade shock (see Panel D in Figure 1) and also in line with the typical finding in developing economies from Vegh and Vuletin (2012) and Federico, Vegh, and Vuletin (2014). If this information was wrongly used to estimate the effect of monetary policy on output, it would give the false impression that increases in IR are more harmful on impact on economic activity that what they truly are (Panels B in Figure 7 versus Figure 10). That is to say, this bias on the monetary front will tend to overestimate the negative output effect of changes in IR policy on impact. These finding reinforces our arguments that the mere use of timing assumptions to identify innovations in macroprudential and monetary policies proves to be a poor identification strategy.

INSERT FIGURE 11

\section{Conclusions}

This paper has shed novel evidence on the true macroeconomic effects of macroprudential policy. The main contribution of the paper has been to correctly identify innovations in reserve 
requirements by following a narrative approach (based on contemporary reports from the IMF and Central Banks) that allows us to distinguish between changes in reserve requirements that were exogenous to the business cycle from those that were endogenous. We also pushed the frontier on the measurement front by creating a novel effective reserve requirement measure which takes into account the structure of deposits as well as on the identification of monetary policy shocks by creating a new central bank interest rate shock series based on Romer and Romer's (2004) approach. We show that pushing the identification front proves to be critical to correctly assessing the output effects of changes in reserve requirements. In particular, when properly identified, an increase in reserve requirements leads to a fall in output. In contrast, when traditional time-based identification methods are followed, an increase in reserve requirements could even depict an expansionary effect in output. We show that the countercyclical nature of endogenous changes in reserve requirements is at the heart of this bias. 


\section{References}

[1] Aikman, David, Bridges, Jonathan, Kashyap, Anil and Siegert, Caspar. 2019. Would macroprudential regulation have prevented the last crisis? Journal of Economic Perspectives 33: 107-130.

[2] Bernanke, Ben, Boivin, Jean and Eliasz, Piotr. 2005. Measuring the effects of monetary policy: A factor-augmented vector autoregressive (FAVAR) approach. Quarterly Journal of Economics 120: 387-422.

[3] Bernanke, Ben, Gertler, Mark and Watson, Mark. 1997. Systematic monetary policy and the effects of oil price shocks. Brookings Papers on Economic Activity 1: 91-142.

[4] Bianchi, Javier and Mendoza, Enrique. 2018. Optimal time-consistent macroprudential policy. Journal of Political Economy 126: 588-634.

[5] Bianchi, Javier, Boz, Emine and Mendoza, Enrique. 2012. Macro-prudential policy in a Fisherian model of financial innovation. IMF Economic Review 60: 223-269.

[6] Bianchi, Javier, Liu, Chenxin and Mendoza, Enrique. 2016. Fundamentals news, global liquidity and macroprudential policy. Journal of International Economics 99, Supplement 1: S2-S15.

[7] Borio, Claudio and Shim, Ilhyock. 2007. What can (macro-)prudential policy do to support monetary policy? BIS Working Paper 242.

[8] Blanchard, Olivier and Perotti, Roberto. 2002. An empirical characterization of the dynamic effects of changes in government spending and taxes on output. Quarterly Journal of Economics 117: 1329-1368.

[9] Calderon, Cesar and Serven, Luis. 2014. Macro-prudential policies over the cycle in Latin America. In S. Schmukler and T. Didier (eds.), Emerging Issues in Financial Development: Lessons from Latin America. The World Bank.

[10] Christiano, Lawrence, Eichenbaum, Martin and Evans, Charles. 1999. Monetary policy shocks: What have we learned, and to what end? In Handbook of Monetary Economics, 1999, Taylor, John, Woodford Michael (eds). Elsevier Science: Amsterdam; 65-148.

[11] Cizel, Janko, Frost, Jon, Houben, Aerdt and Wierts, Peter. 2019. Effective macroprudential policy: Cross-sector substitution from price and quantity measures. Journal of Money, Credit and Banking 51(5): 1209-1235.

[12] Claessens, Stijn and Ghosh, Swati. 2012. Macro-prudential policies: Lessons for and from emerging markets. IMF and World Bank unpublished manuscript.

[13] Coibion, Olivier. 2012. Are the effects of monetary policy shocks big or small? American Economic Journal: Macroeconomics 4: 1-32.

[14] Crowe, Christopher, Dell'Ariccia, Giovanni, Igan, Deniz and Rabanal, Pau. 2013. How to deal with real estate booms: Lessons from country experiences. Journal of Financial Stability 9: 300-319. 
[15] De Gregorio, Jose, Edwards, Sebastian and Valdes, Rodrigo. 2000. Controls on capital inflows: Do they work? Journal of Development Economics 63: 59-83.

[16] De la Torre, Augusto, Ize, Alain and Schmukler, Sergio. 2012. Financial development in Latin America and the Caribbean. World Bank: Latin American and Caribbean Studies.

[17] Disyatat, Piti and Vongsinsirikul, Pinnarat. 2003. Monetary policy and the transmission mechanism in Thailand. The Journal of Asian Economics 14: 389-418.

[18] Federico, Pablo, Vegh Carlos and Vuletin, Guillermo. 2014. Reserve requirement policy over the business cycle. NBER Working Paper 20612.

[19] Fischer, Stanley. 1998 .The IMF and the Asian Crisis. Speech delivered at UCLA (available on the IMF website).

[20] Glocker, Christian and Towbin, Pascal. 2012. The macroeconomic effects of reserve requirements. WIFO Working Paper 420.

[21] Gray, Simon. 2011. Central bank balances and reserve requirements. IMF Working Paper $11 / 36$.

[22] International Monetary Fund. Western Hemisphere Department. 2011. Regional Economic Outlook, October 2011, Western Hemisphere: Shifting Winds, New Policy Challenges. IMF.

[23] Izquierdo, Alejandro, Loo-Kung, Rudy and Rojas-Suarez, Liliana. 2013. Macroprudential regulations in Central America. Center for Global Development Working Paper 318 .

[24] Jiménez, Gabriel, Ongena Steven, Peydró José-Luis and Suarina Jesús. 2017. Macroprudential policy, countercyclical bank capital buffers, and credit supply: Evidence from the Spanish dynamic provisioning experiments. Journal of Political Economy, 125: 21262177 .

[25] Jordà, Òscar. 2005. Estimation and inference of impulse responses by local projections. American Economic Review 95: 161-182.

[26] Korinek, Anton. 2011. The new economics of prudential capital controls: A research agenda. IMF Economic Review 59: 523-561.

[27] Lahiri, Amartya and Vegh, Carlos. 2003. Delaying the inevitable: Interest rate defense and balance of payments crisis. Journal of Political Economy 111: 404-424.

[28] Le, Viet. 2009. A Vector Autoregression (VAR) analysis of the monetary transmission mechanism in Vietnam. Mimeo (National Graduate Institute for Policy Studies, Vietnam).

[29] Leeper, Eric, Sims, Christopher and Zha, Tao. 1996. What does monetary policy do? Brookings Papers on Economic Activity 2: 1-78. 
[30] Lim, Cheng, Columba, Francesco, Costa, Alejo, Kongsamut, Piyabha, Otani, Akira, Saiyid, Mustafa, Wezel, Torsten and Wu, X. 2011. Macroprudential policy: What instruments and how to use them? IMF Working Paper 11/238.

[31] Ma, Guonan, Xiandong, Yan and Xi, Liu. 2013. China's evolving reserve requirements. Journal of Chinese Economic and Business Studies 11: 117-137.

[32] Meeks, Roland. 2017. Capital regulation and the macroeconomy: Empirical evidence and macroprudential policy. European Economic Review 95: 125-141.

[33] Mendoza, Enrique. 2016. Macroprudential policy: Promise and challenges. NBER Working Paper 22868.

[34] Montoro, Carlos and Moreno, Ramon. 2011. The use of reserve requirements as a policy instrument in Latin America. BIS Quarterly Review.

[35] Ostry, Jonathan, Ghosh, Atish, Habrermeir, Karl, Chamon, Marcos, Qureshi, Mahvash and Reinhardt, Dennis. 2010. Capital inflows: The role of controls. IMF Staff Position Note 10/04.

[36] Powell, Andrew. 2012. The world of forking paths: Latin America and the Caribbean facing global economic risks. Inter-American Development Bank, Working Paper 4766.

[37] Quizpe, Zenon and Rossini, Renzo. 2010. Monetary policy during the global financial crisis of 2007-2009: The case of Peru. BIS Paper 54: 299-316..

[38] Reinhart, Carmen, Rogoff, Kenneth and Savastano, Miguel. 2003. Addicted to dollars. NBER Working Paper 10015.

[39] Riera-Crichton, Daniel, Vegh, Carlos and Vuletin, Guillermo. 2016. Tax multipliers: Pitfalls in measurement and identification. Journal of Monetary Economics 79: 30-48.

[40] Romer, Christina and Romer, David. 2004. A new measure of monetary shocks: Derivation and implications. American Economic Review 94: 1055-1084.

[41] Romer, Christina and Romer, David. 2010. The macroeconomic effects of tax changes: Estimates based on a new measure of fiscal shocks. American Economic Review 100: 763-801.

[42] Stock, James and Watson, Mark. 2007. Why has U.S. inflation become harder to forecast? Journal of Money, Credit and Banking 39: 3-33.

[43] Strauss, Delphine. 2010. Capital inflows to Turkey spur rate cut plan. Financial Times, December 13, 2010.

[44] Terrier, Gilbert, Valdes, Rodrigo, Tovar, Camilo, Chan-Lau, Jorge, FernándezValdovinos, Carlos, García-Escribano, Mercedes, Medeiros, Carlos, Tang, Man-Keung, Vera-Martin, Mercedes and Walker, Christopher. 2011. Policy instruments to lean against the wind in Latin America. IMF Working Paper 159.

[45] Teulings, Coen, Nikolay Zubanov. 2014. Is economic recovery a myth? Robust estimation of impulse responses. Journal of Applied Econometrics 29: 497-514. 
[46] Tovar, Camilo, Garcia-Escribano, Mercedes and Vera-Martin, Mercedes. 2012. Credit growth and the effectiveness of reserve requirements and other macroprudential instruments in Latin America. IMF Working Paper 142.

[47] Vargas, Hernando, Betancourt, Yanneth, Rodriguez, Norberto and Varela, Carlos. 2010. Effects of reserve requirements in an inflation targeting regime: The case of Colombia. BIS Papers 54: 133-170.

[48] Vegh, Carlos and Vuletin, Guillermo. 2012. Overcoming the fear of free falling: Monetary policy graduation in emerging markets. NBER Working Paper 18175.

[49] Vegh, Carlos and Vuletin, Guillermo. 2015. Unsticking the flypaper effect in an uncertain world. Journal of Public Economics 131: 142-155. 


\section{Appendix. Definition and sources of variables}

All data are at quarterly frequency.

Real GDP: Data is from the Global Economic Monitor, World Bank and respective central banks. GDP is seasonal adjusted.

Monetary policy rate: We take short-term interest rates as a proxy for the stance of monetary policy. For Brazil we used the SELIC. The SELIC is the target rate for overnight interbank loans collateralized by government bonds, register with and traded on the Sistema Especial de Liquidacao e Custodia (IFS/IMF). For Argentina we used the monetary policy rate from the central bank. ${ }^{20}$ For Uruguay we used the money market rate, i.e. the overnight rate on loans between private banks (IFS, IMF). Data is from IFS/IMF and local central banks.

Interest rate spread: Lending minus deposit interest rates, according to the definitions used by the IFS, IMF. Sources: IFS/IMF.

Legal reserve requirements: Data is from local sources and papers: Argentina (Central Bank of Argentina: data accessed at www.bcra.gov.ar on March 2012. Go to: Estadisticas e indicadores/ Monetarias y financieras/ Descarga de paquetes estadísticos/ Dinero y créditos/Información relacionada con la normativa de regulación de liquidez del BCRA, serie mensual. The rate applicable to term deposits corresponds to deposits with maturities of between 30 and 60 days), Brazil (Eliana Cardoso (2003) "Seigniorage, Reserve Requirements and Bank Spreads in Brazil" in Taxation of Financial Intermediation: Theory and Practice for Emerging Economies. Favia de Carvalho and Cyntia Azevedo (2008) "The Incidence of Reserve Requirements in Brazil: Do Bank Stockholders share the Burden?" Central Bank of Brazil Working Papers Series 160. Patrice Robitaille (2011) "Liquidity and Reserve Requirements in Brazil" International Finance Discussion Papers 1021. The rate applicable to demand and time deposits corresponds to non-remunerated deposits for "Region A", defined as the sum of the regions less Acre, Amazonas, Pará, Maranhão, Piauí, Ceará, Rio Grande do Norte, Paraíba, Pernambuco, Alagoas, Sergipe, Bahia, Espírito Santo, Goiás, Mato Grosso. We also use information from Reuters, available at www.reuters.com, and from the Central Bank of Uruguay (we thank Carolina Martino at the Central Bank of Uruguay for data assistance. The rate applicable to term deposits corresponds to deposits with a maturity lower than a year).

Inflation: Based on consumer price index. Source: IFS/IMF.

Nominal exchange rate: Nominal bilateral exchange rate (against USD). Source: IFS/IMF.

\footnotetext{
${ }^{20}$ Visit the Central Bank of Argentina website for more details.
} 
Figure 1. Cumulative response to a one percent increase in terms of trade shock

\section{Panel A. Response of GDP}

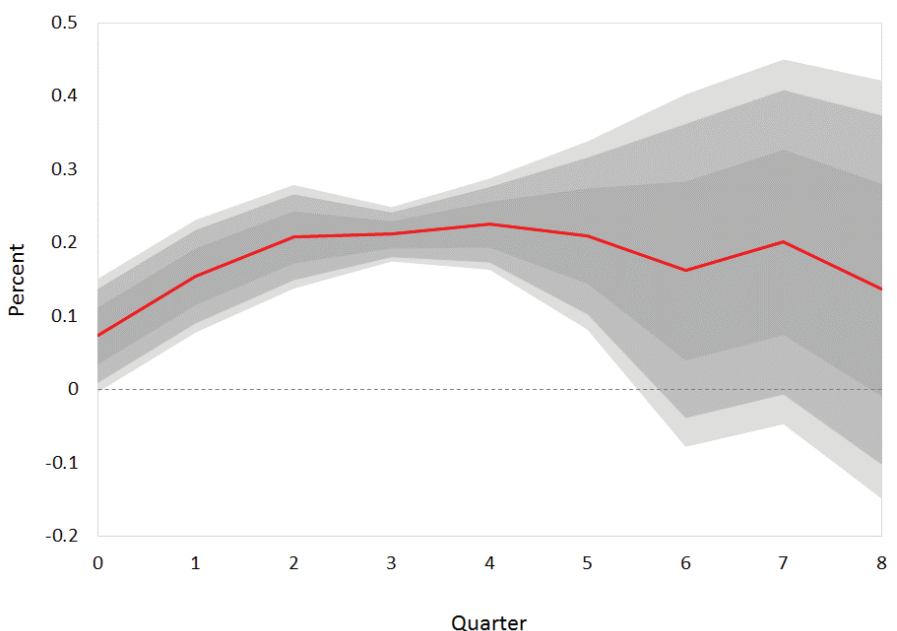

Panel C. Response of inflation

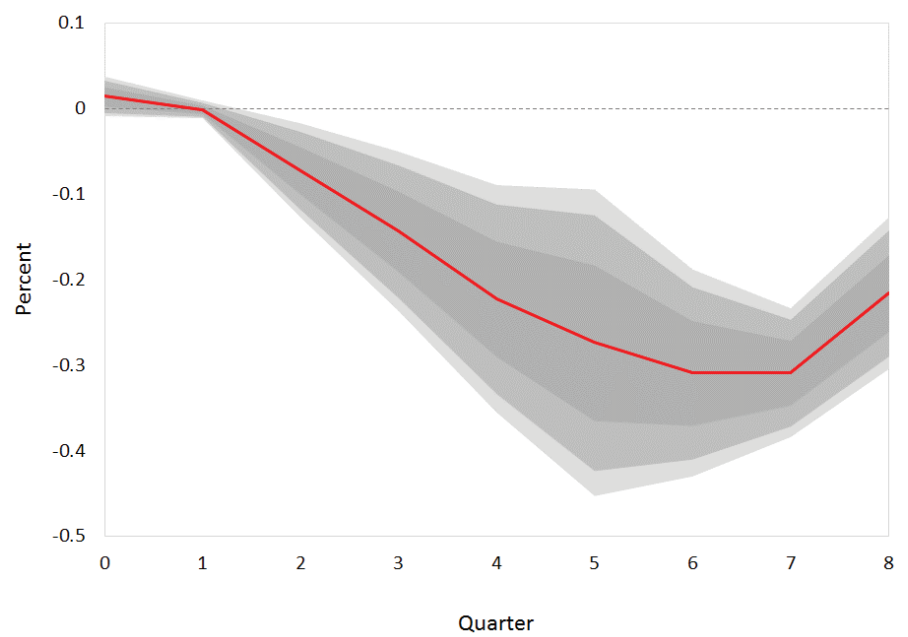

Panel E. Response of legal reserve requirement

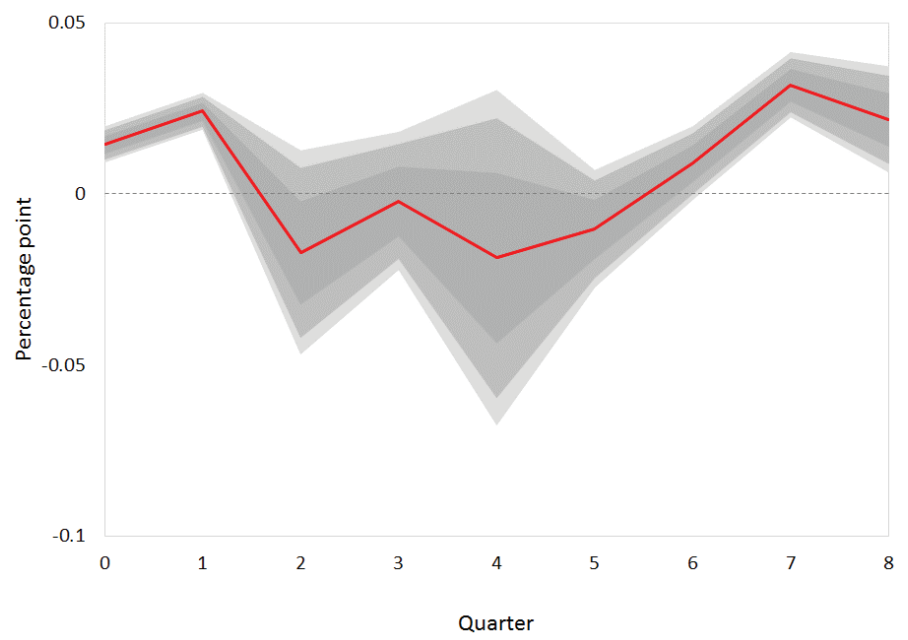

Panel B. Response of exchange rate (a decrease means an appreciation)

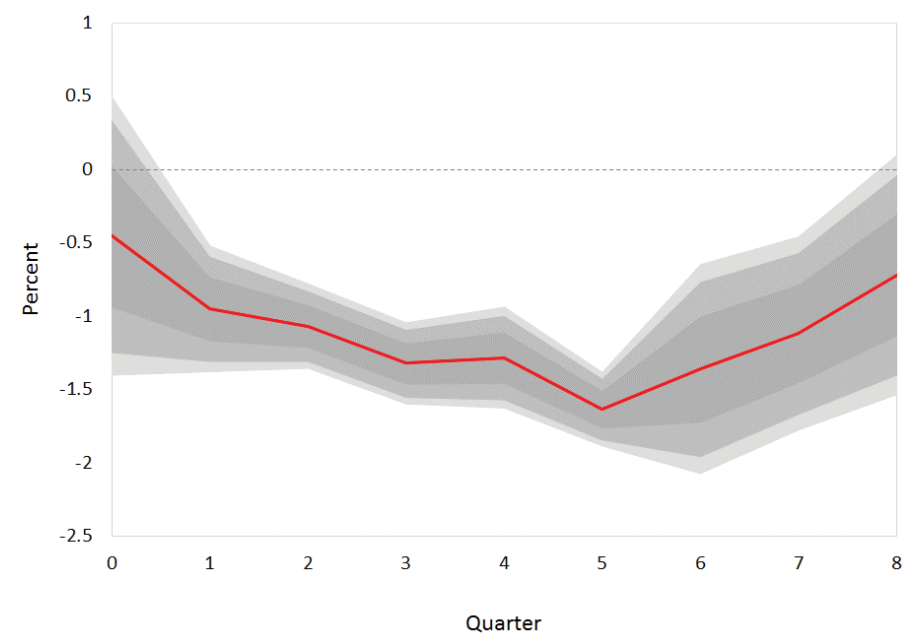

Panel D. Response of central bank interest rate

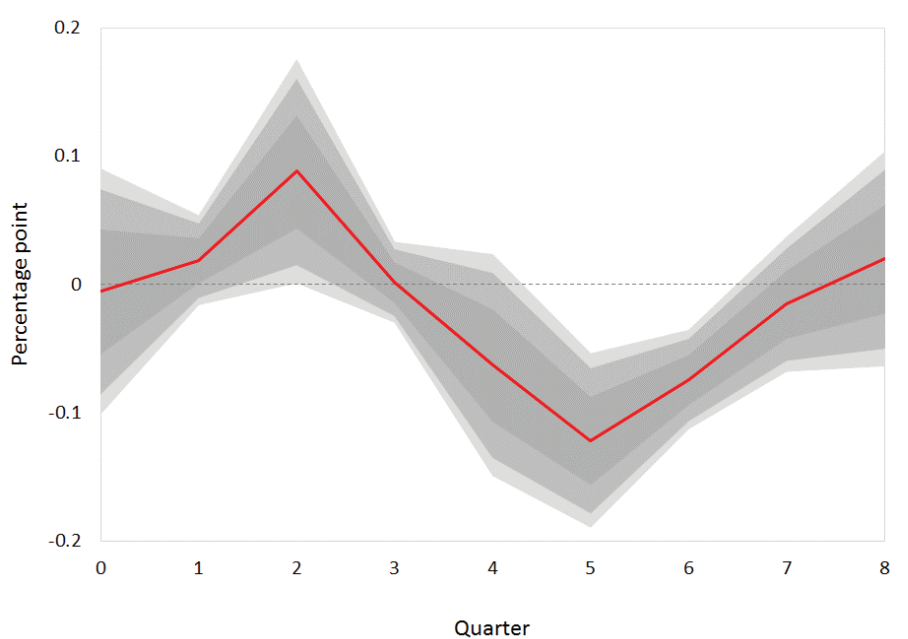

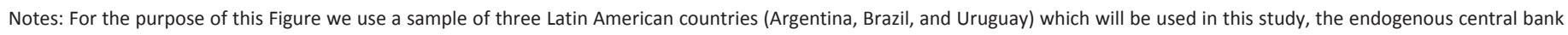

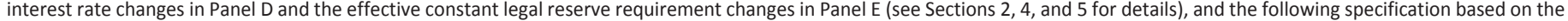

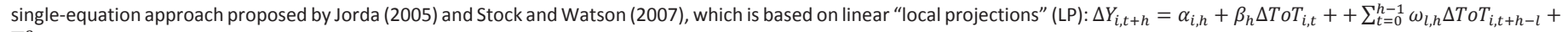

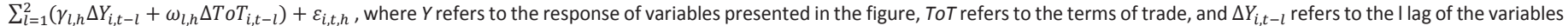

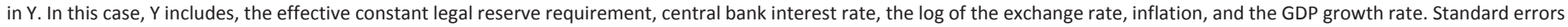
clustered at country level. Dark, medium, and light grey areas show 68, 90, and 95 percent confidence intervals, respectively. 
Figure 2. Levels of legal reserve requirements

Panel A. Argentina: 1990:1-2018:1

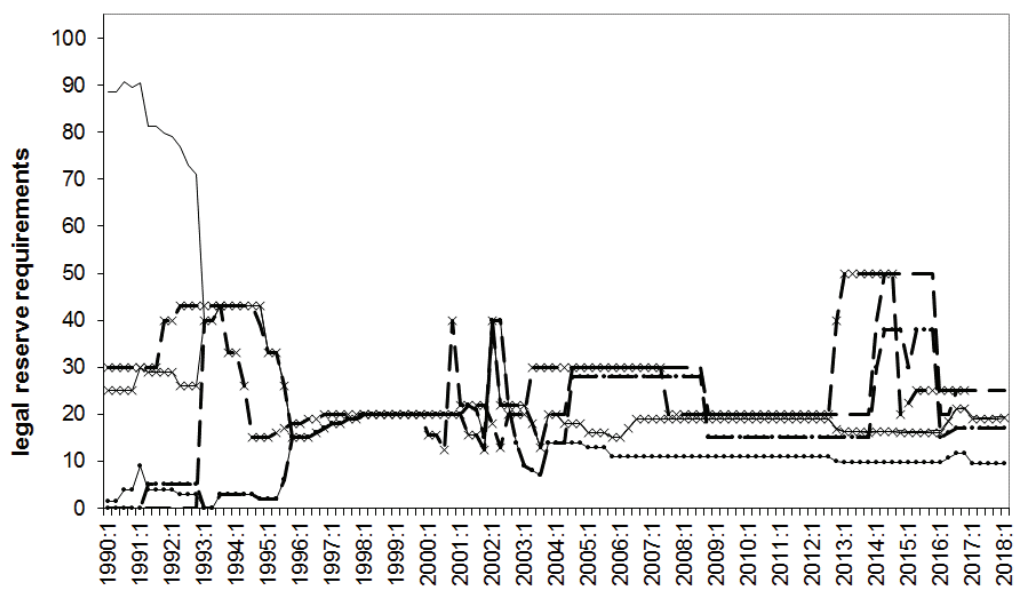

$\begin{array}{lll}- \text {-local-demand } & * \text {-local-saving } & \rightarrow \text { local-term } \\ \text { - foreign-demand } & \rightarrow \text {-foreign-saving } & - \text {-foreign-term }\end{array}$

Panel B. Brazil: 1994:3-2018:2

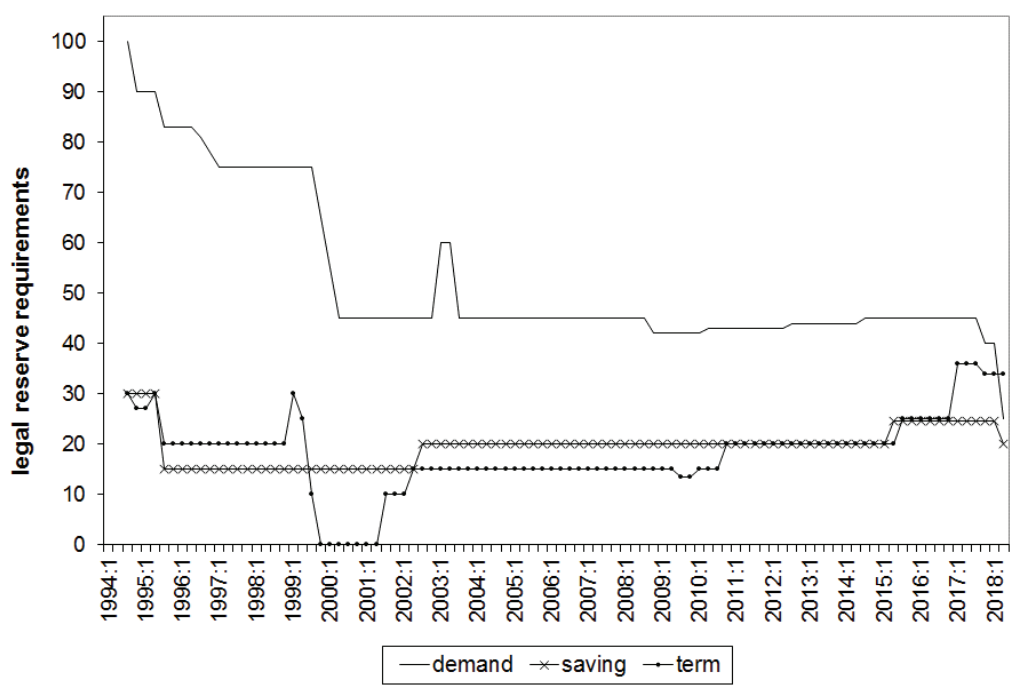

Panel D. Uruguay: 1990:1-2018:2

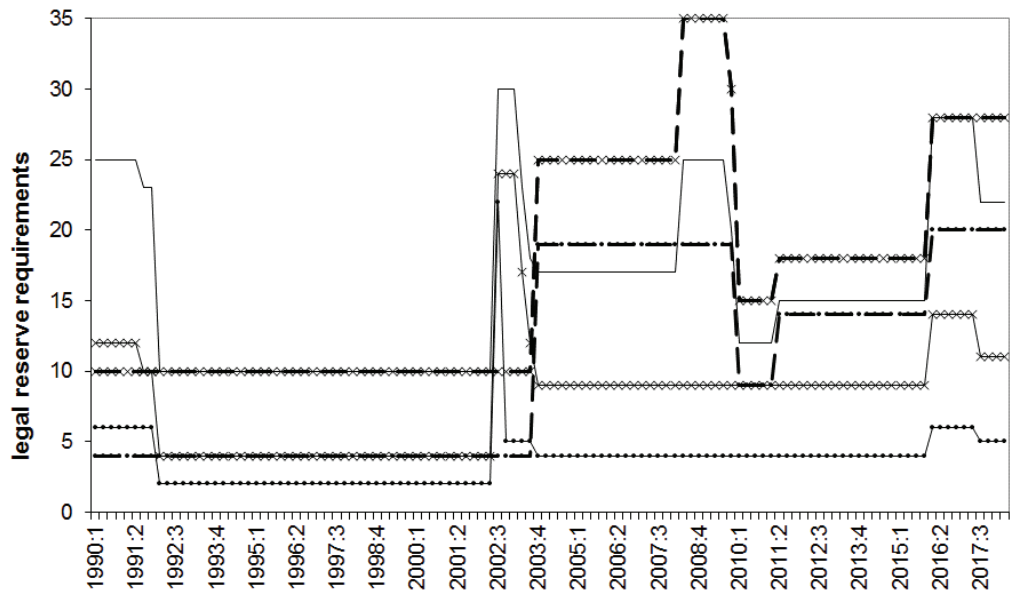

-local-demand $\quad \star$ local-saving $\quad \rightarrow$ local-term

- foreign-demand $\rightarrow$ foreign-saving - -foreign-term 
Figure 3. Mean and standard deviation of legal reserve requirements

Panel A. Argentina: 1990:1-2018:1

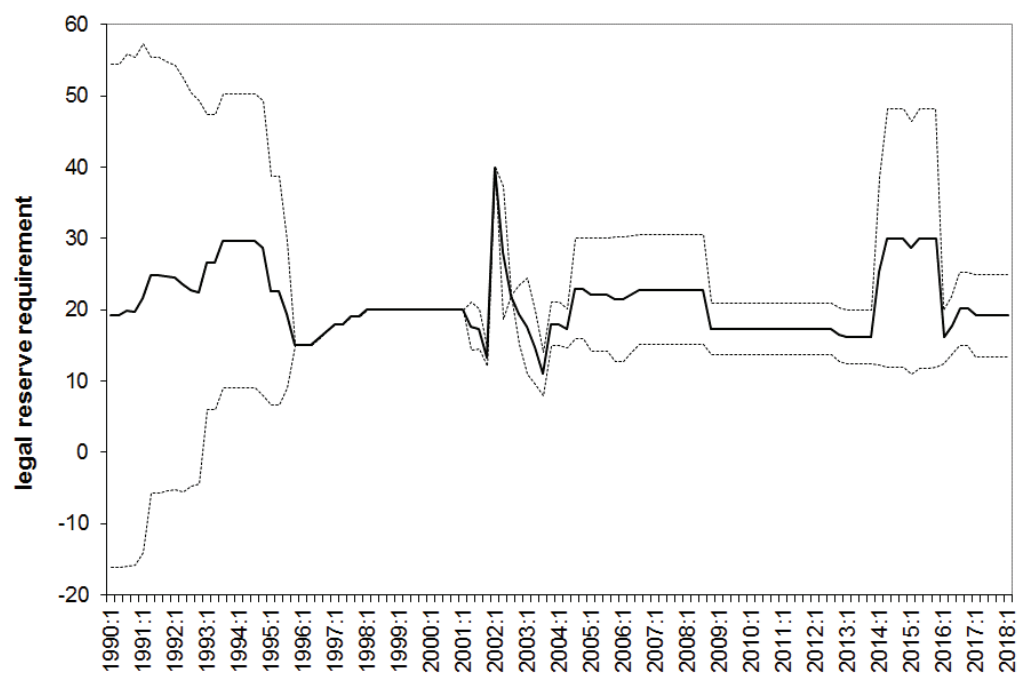

Panel B. Brazil: 1994:3-2018:2

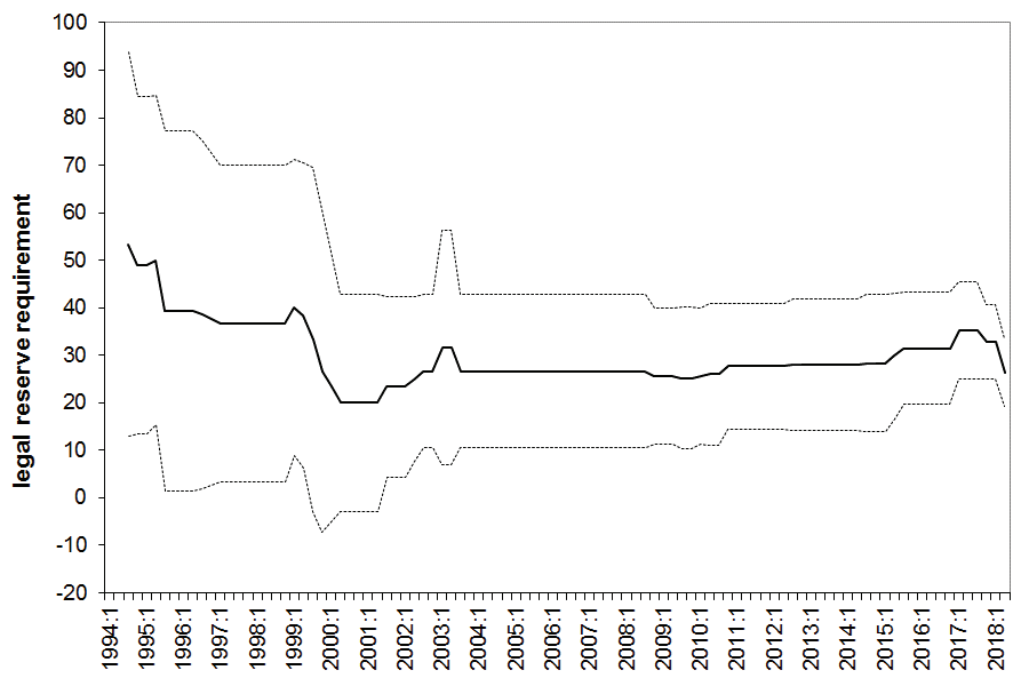

Panel D. Uruguay: 1990:1-2018:2

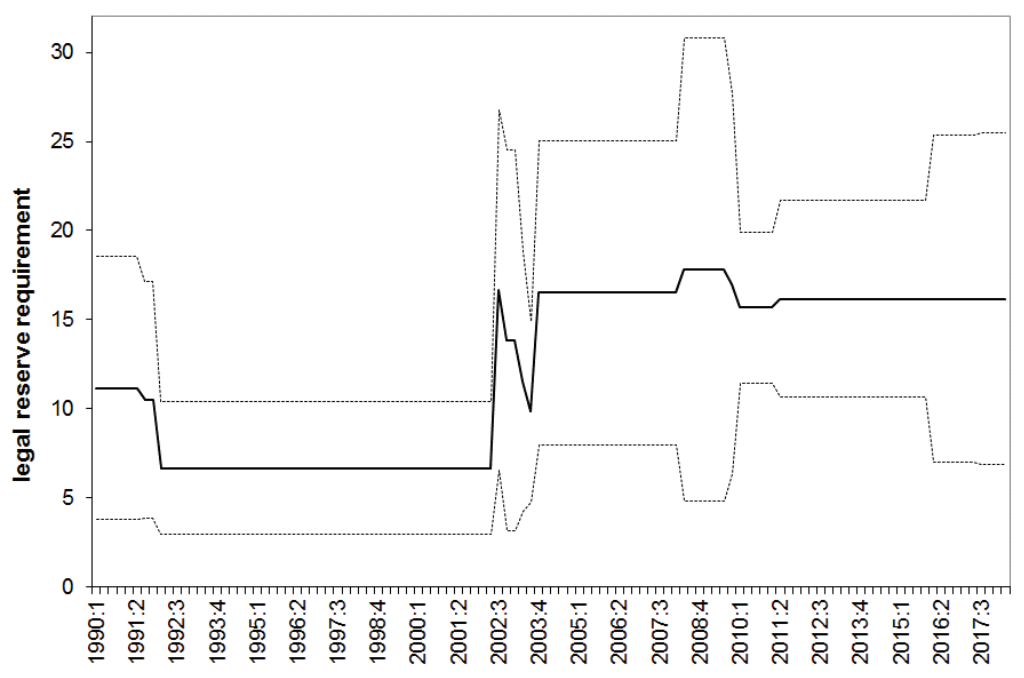


Figure 4. Changes in legal reserve requirements

Panel A. Argentina: 1990:1-2018:1

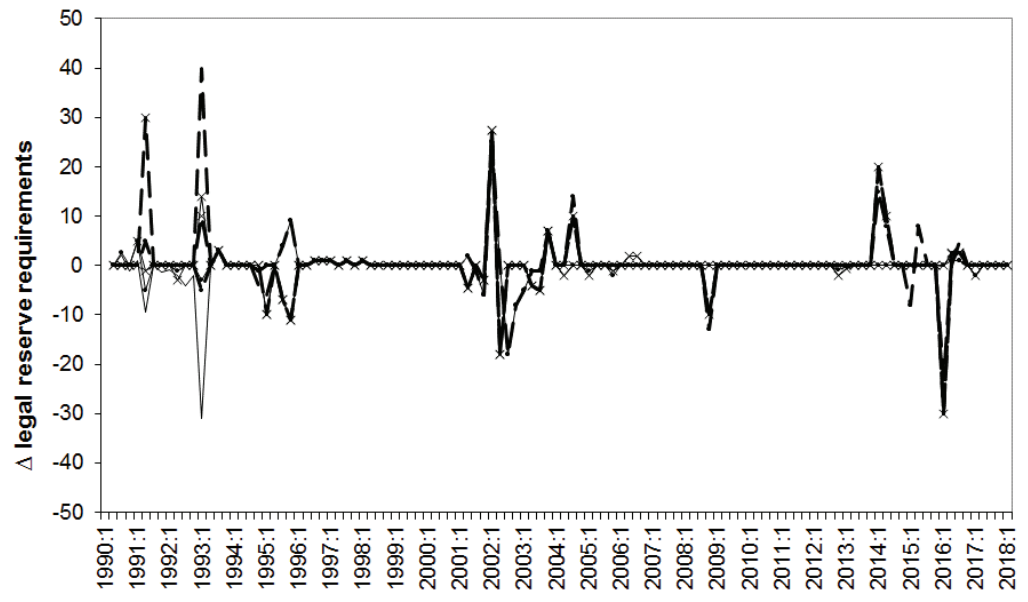

$\begin{array}{lll}\text { - local-demand } & \rightarrow \text { local-saving } & \rightarrow \text {-local-term } \\ \text { - foreign-demand } & \rightarrow \text {-foreign-saving } & - \text {-foreign-term }\end{array}$

Panel B. Brazil: 1994:3-2018:2

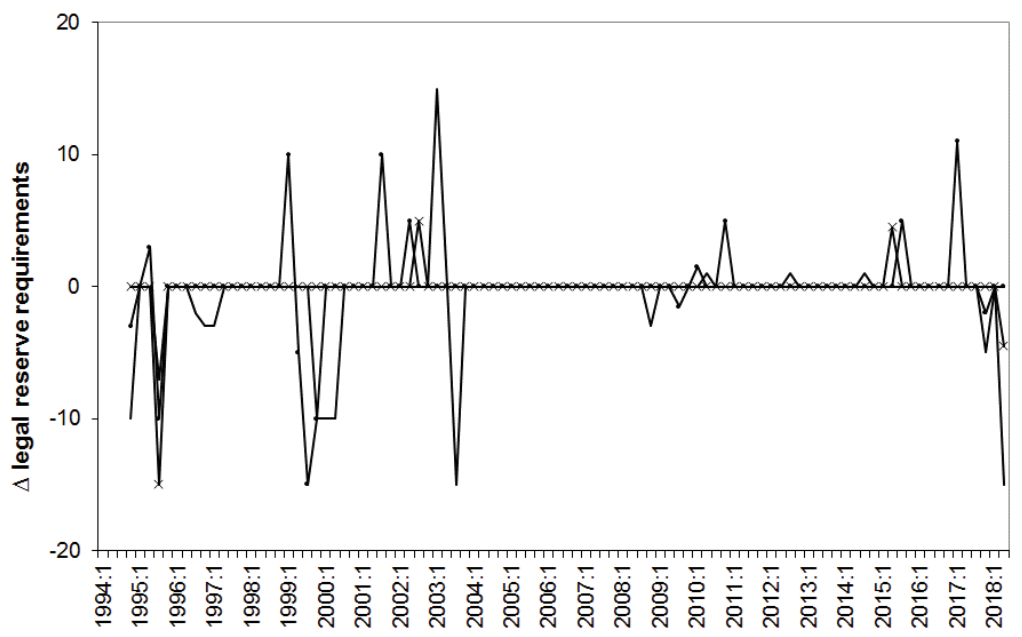

-demand $\rightarrow$ saving $\rightarrow$ term

Panel D. Uruguay: 1990:1-2018:2

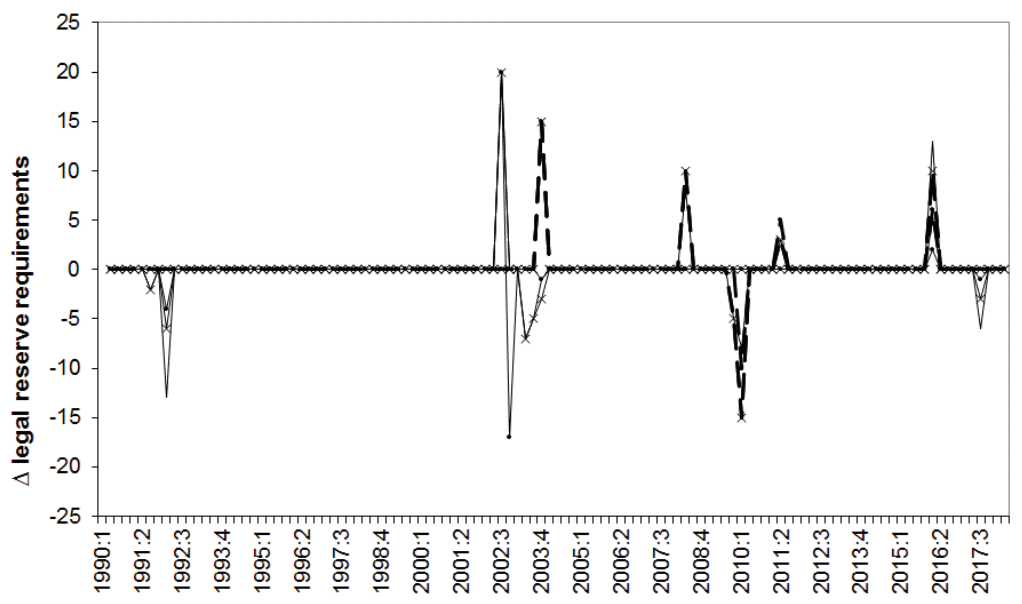

\begin{tabular}{lll}
\hline - local-demand & $\rightarrow$ local-saving & $\rightarrow$-local-term \\
- foreign-demand & $\rightarrow$-foreign-saving & - -foreign-term
\end{tabular} 
Figure 5. Change in effective constant legal reserve requirements

Panel A. Argentina: 1990:1-2018:1

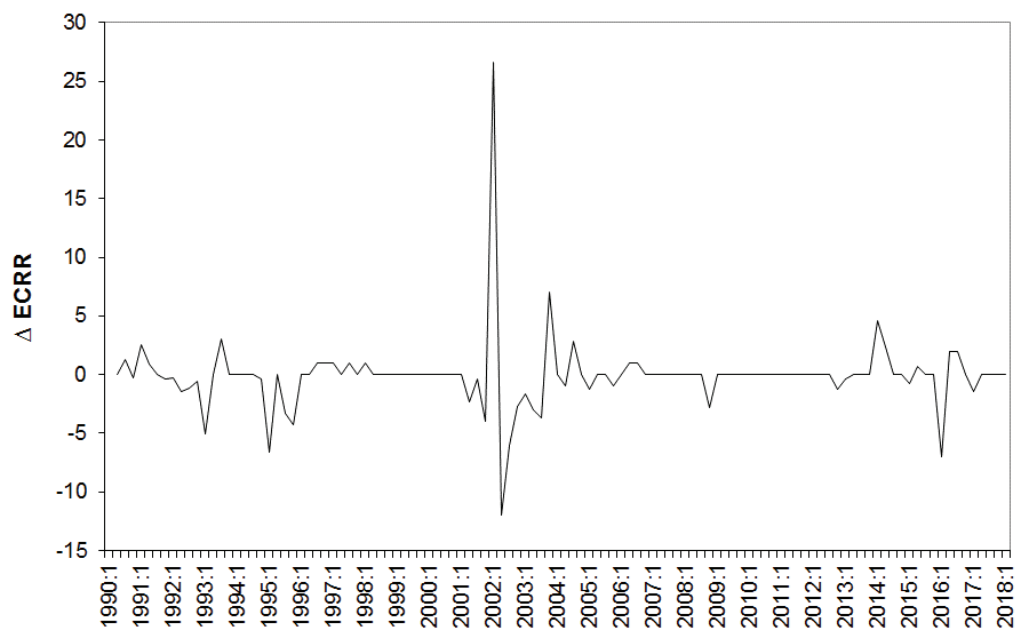

Panel B. Brazil: 1994:3-2018:2

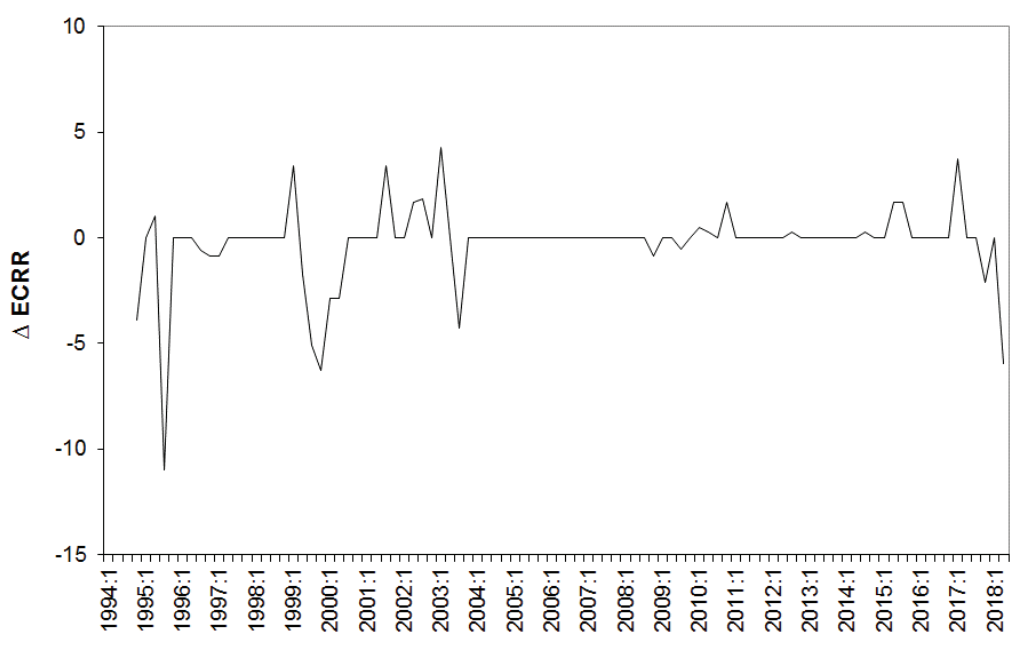

Panel D. Uruguay: 1990:1-2018:2

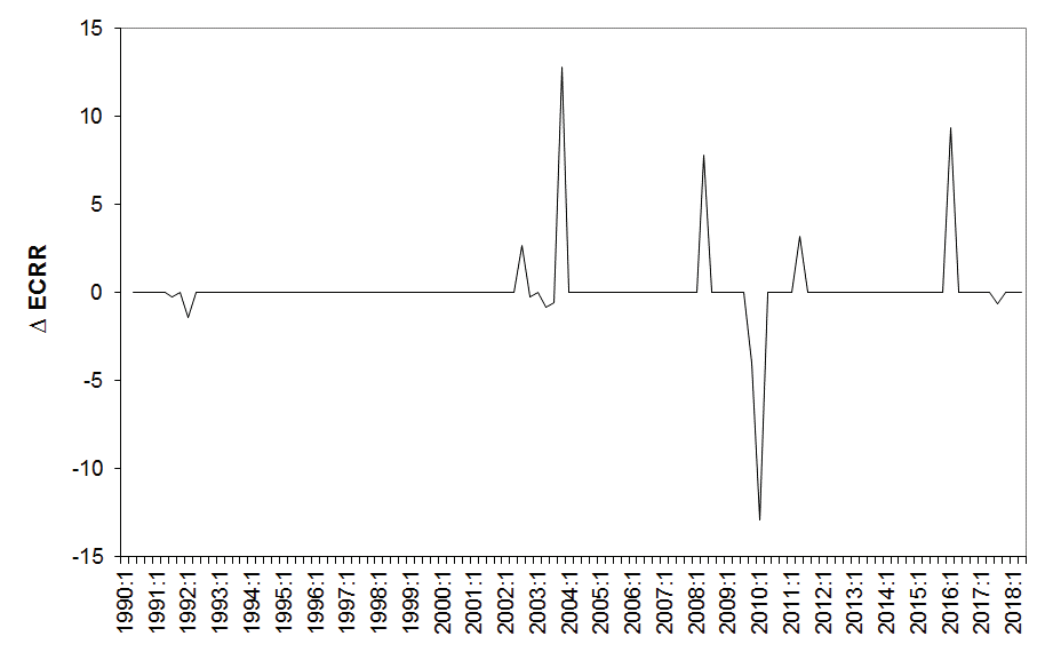

Notes: ECRR stands for effective constant legal reserve requirements. See Section 2.3 for details regarding the construction of ECRR. 
Figure 6. Cumulative response of GDP to a one-percentage-point one-at-a-time increase in central bank interest rate (IR) and effective constant reserve requirement (ECRR) shocks, not allowing for a contemporaneous effect of IR and ECRR shocks on GDP
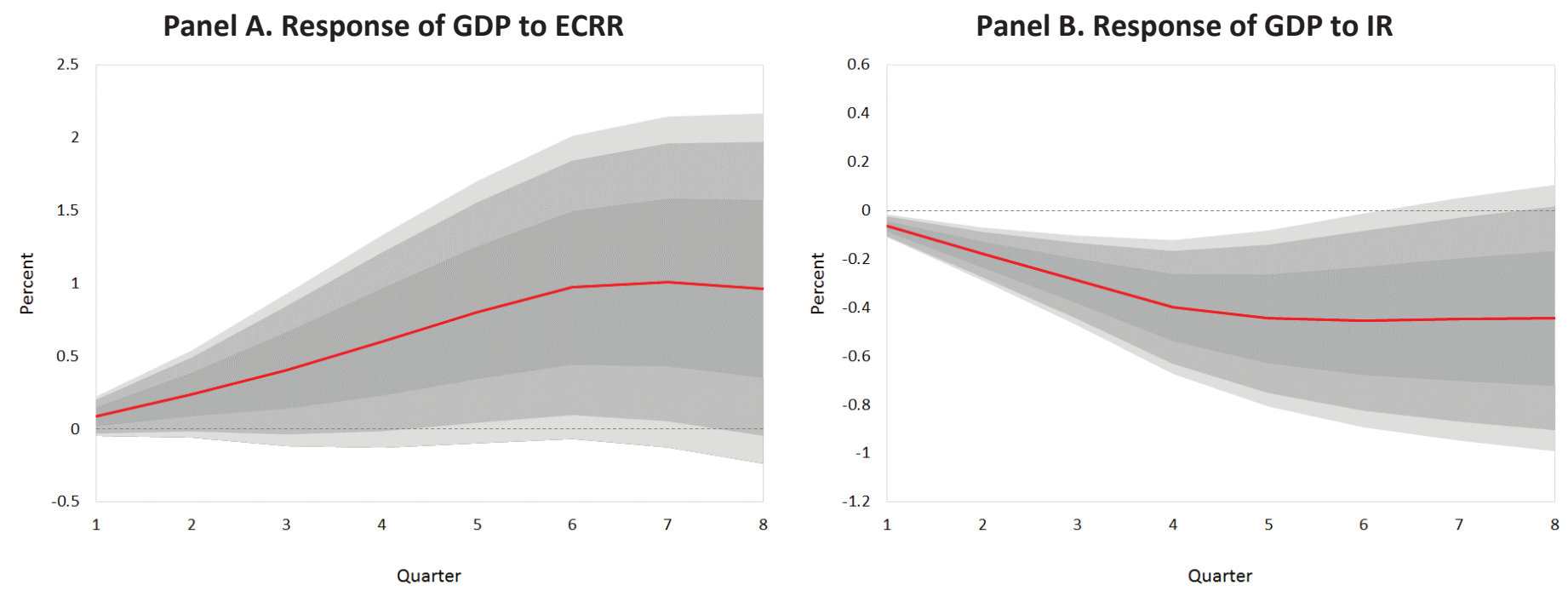

Notes: Dark, medium, and light grey areas show 68, 90, and 95 percent confidence intervals, respectively. Confidence intervals based on 1000 Monte-Carlo simulations.

Figure 7. Cumulative response of GDP to a one-percentage-point one-at-a-time increase in central bank interest rate (IR) and effective constant reserve requirement (ECRR) shocks, allowing for a contemporaneous effect of IR and ECRR shocks on GDP
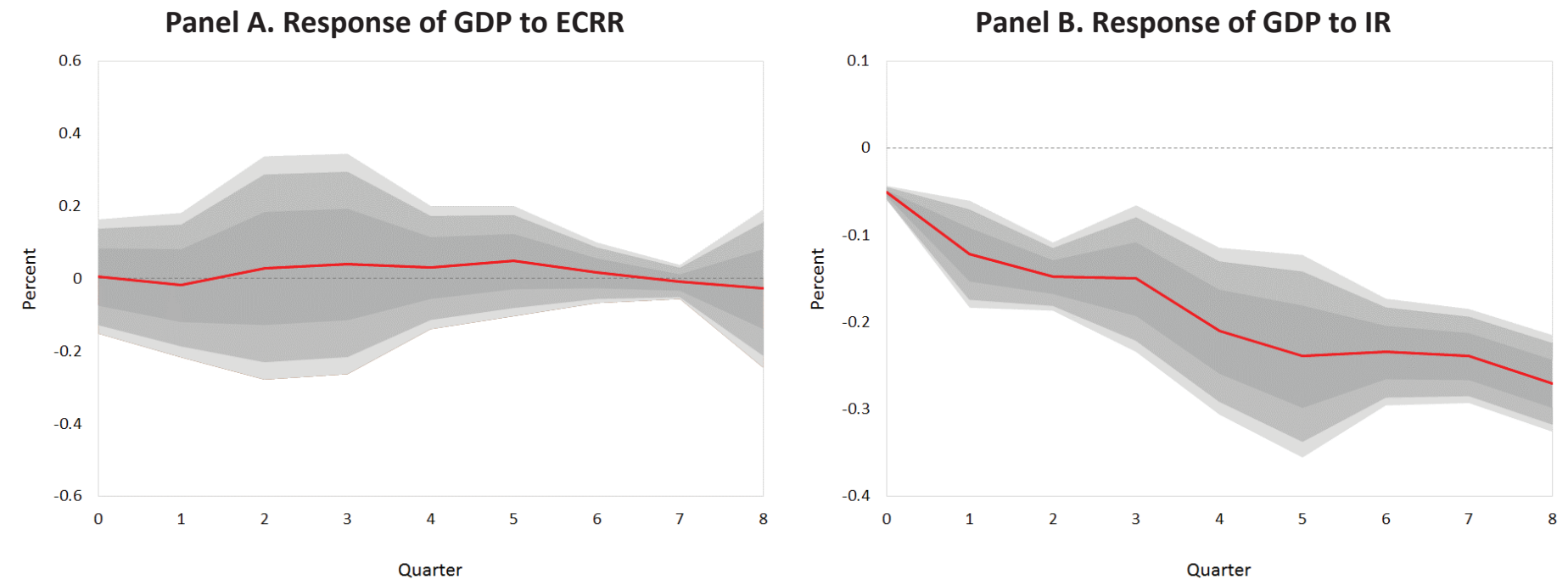

Notes: Dark, medium, and light grey areas show 68, 90, and 95 percent confidence intervals, respectively. Standard errors are clustered at country level. 
Figure 8. Endogenous and exogenous changes in effective constant reserve requirements (ECRR)

Panel A. Argentina: Endogenous and exogenous

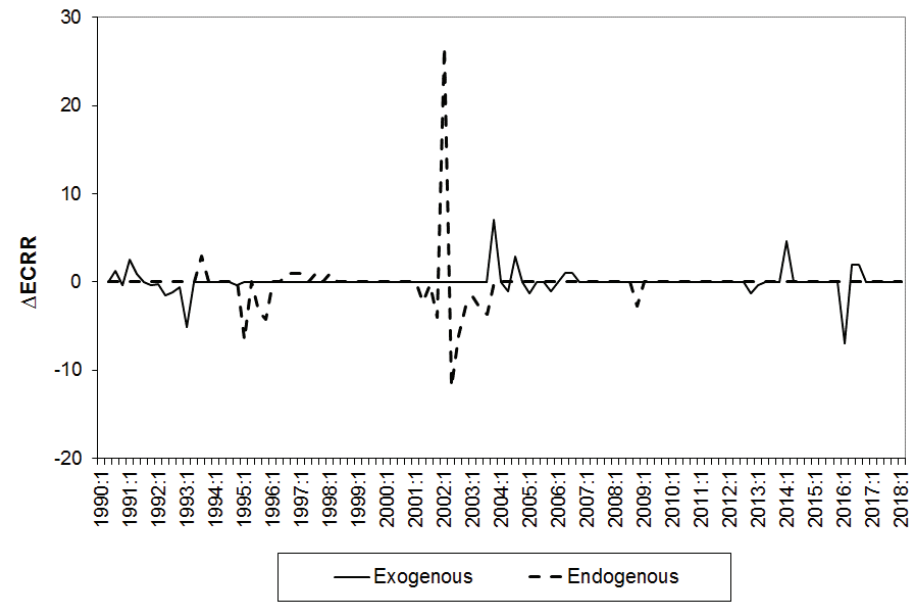

Panel C. Brazil: Endogenous and exogenous

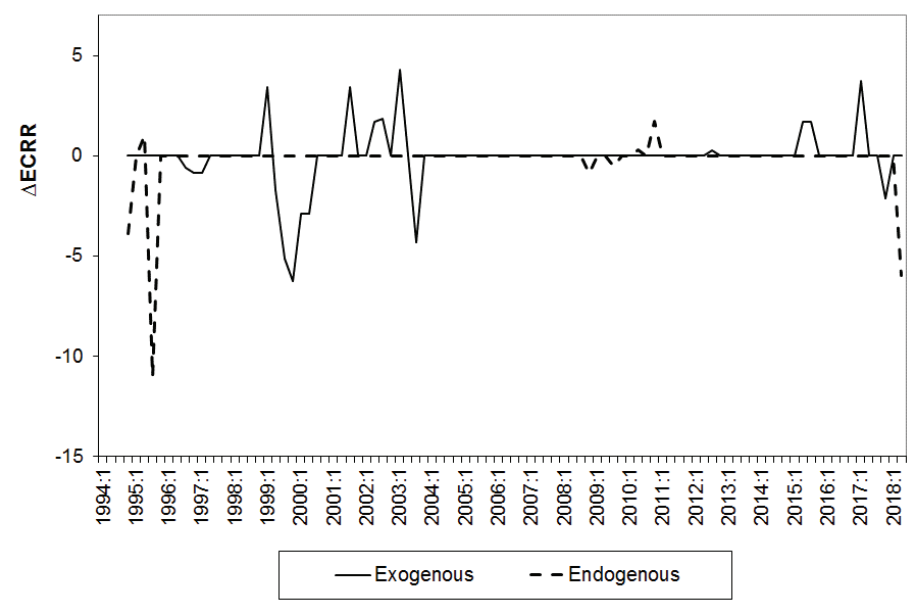

Panel E. Uruguay: Endogenous and exogenous

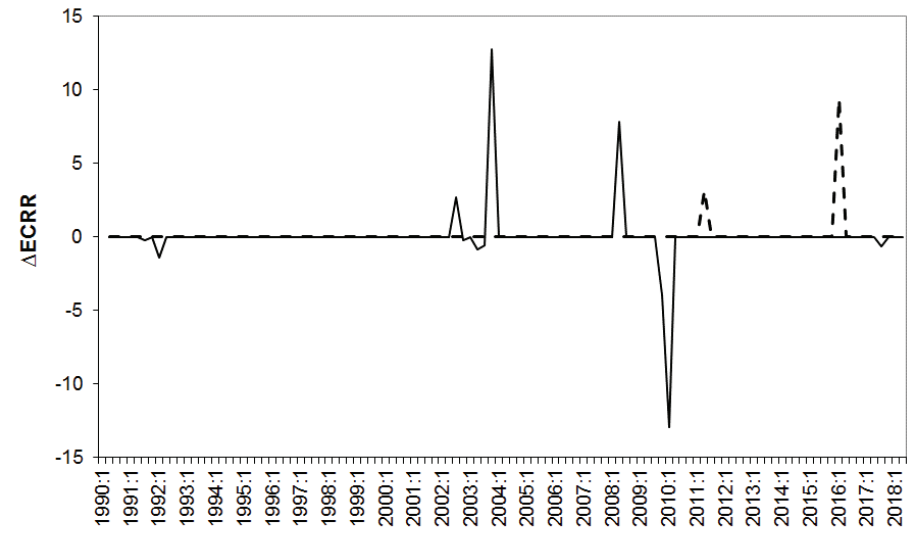

Panel B. Argentina: Endogenous, good and bad times

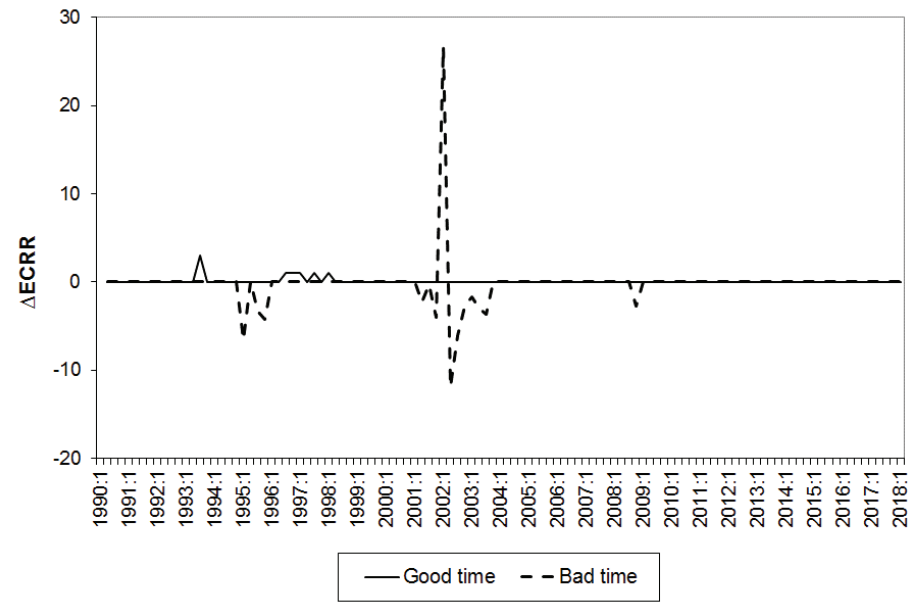

Panel D. Brazil: Endogenous, good and bad times

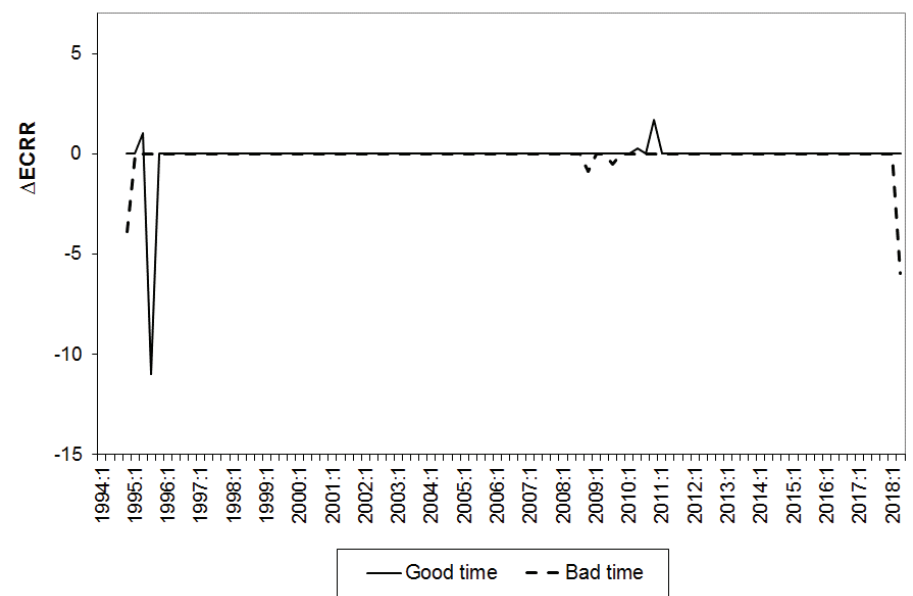

Panel F. Uruguay: Endogenous, good and bad times

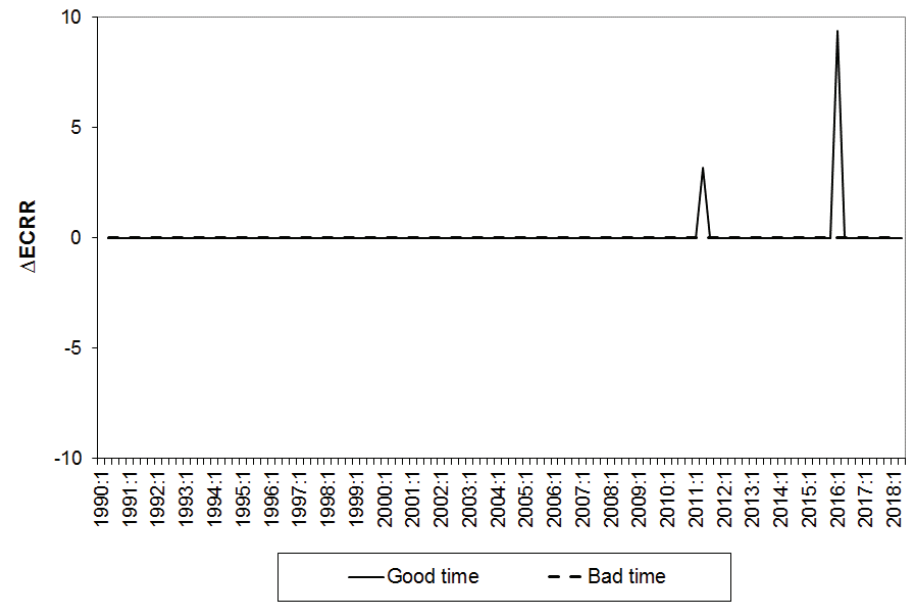

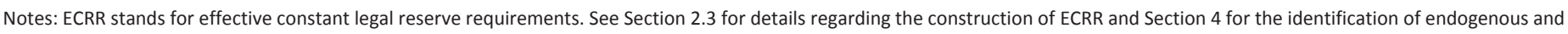
exogenous changes in legal reserve requirements. 
Figure 9. Endogenous and exogenous changes in central bank interest rate (IR)

Panel A. Argentina: Endogenous and exogenous

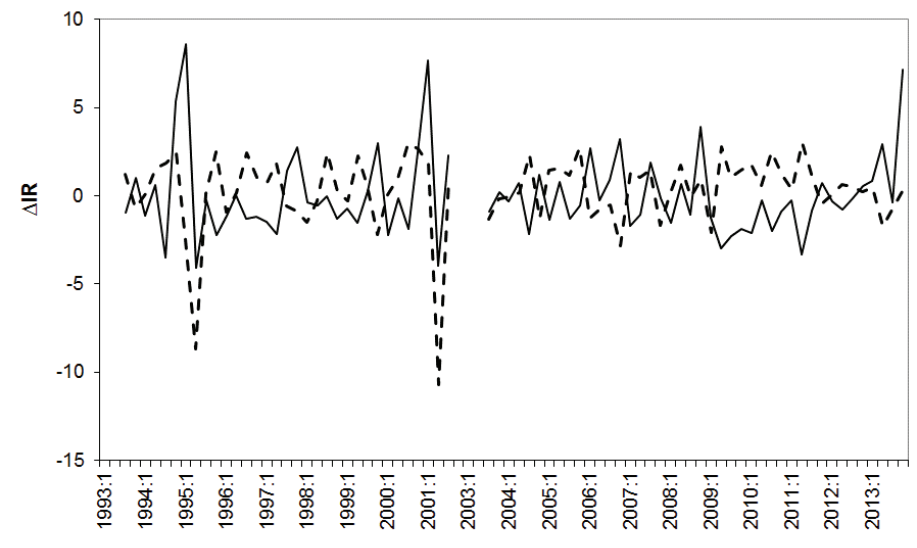

$$
\text { -Exogenous - - Endogenous }
$$

Panel B. Brazil: Endogenous and exogenous

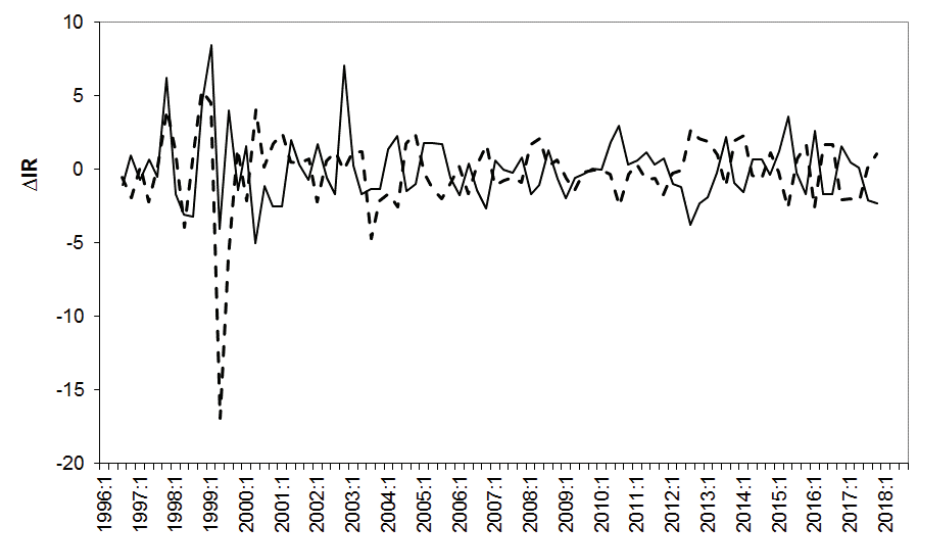

-Exogenous - - Endogenous

Panel D. Uruguay: Endogenous and exogenous

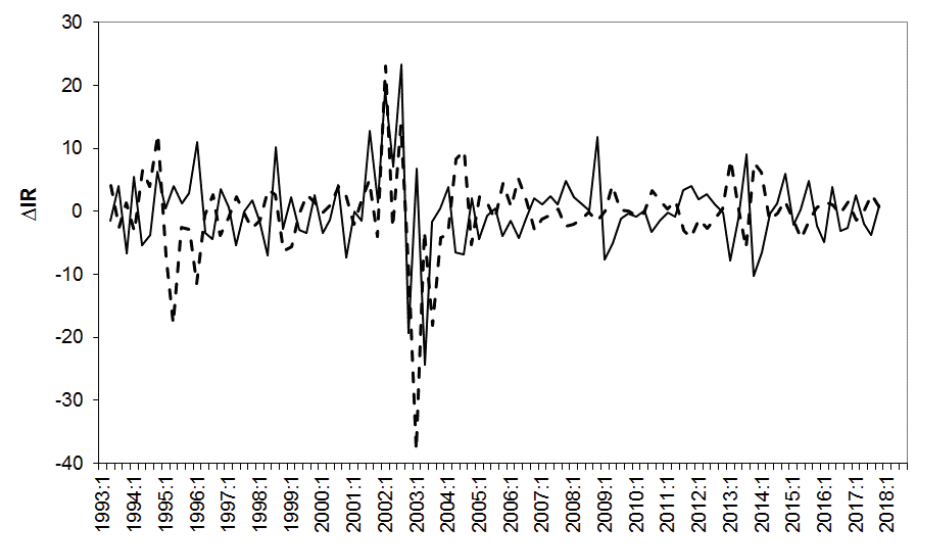

$$
\text { - Exogenous - Endogenous }
$$

Notes: IR stands for central bank interest rate. See Section 5 for the identification of endogenous and exogenous changes in central bank interest rates. 
Figure 10. Cumulative response of GDP to a one-percentage-point one-at-a-time increase in central bank interest rate (IR) and effective constant reserve requirement (ECRR) exogenous shocks

Panel A. Response of GDP to ECRR

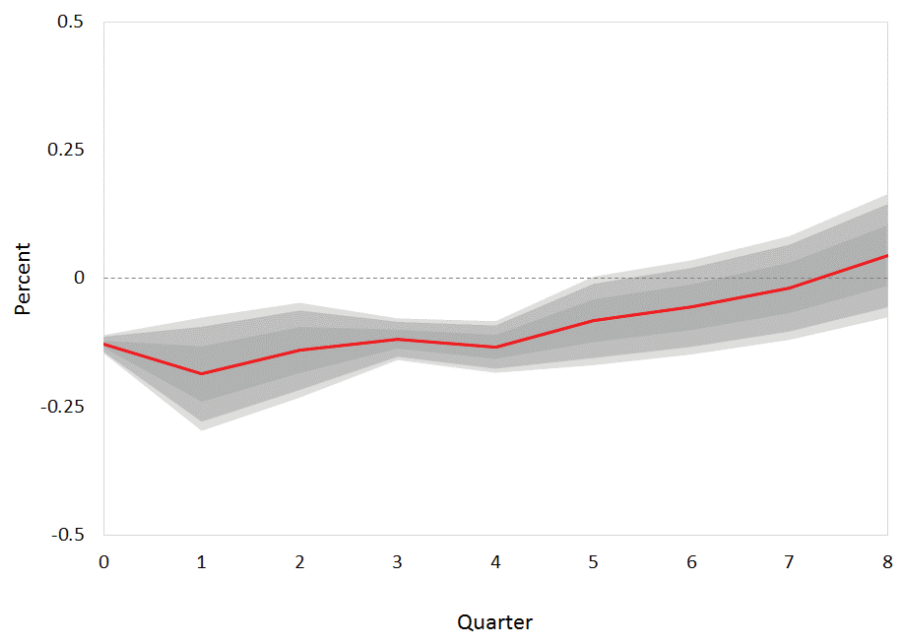

Panel C. Response of market interest rate spread to ECRR

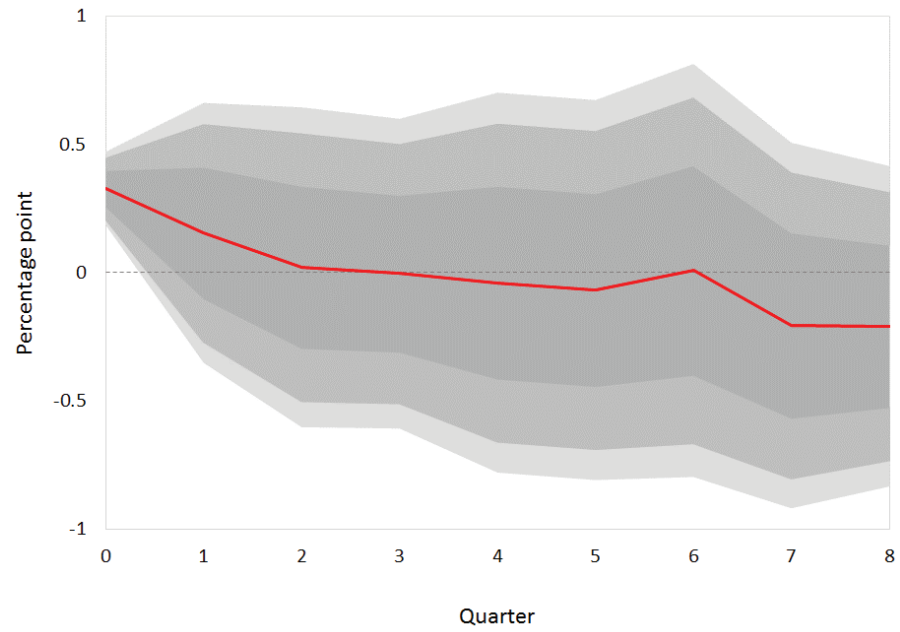

Panel B. Response of GDP to IR

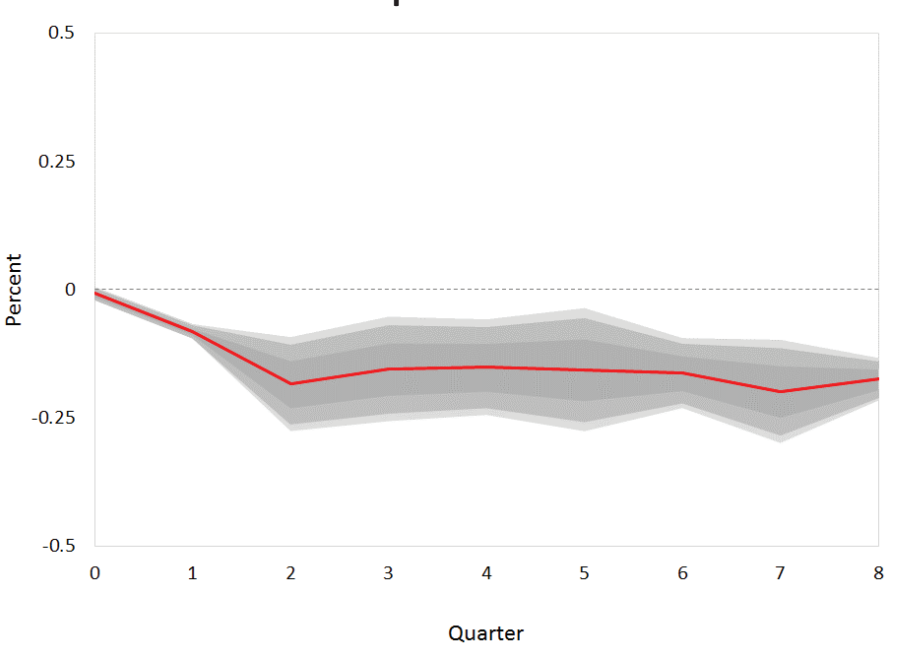

Panel D. Response of market interest rate spread to IR

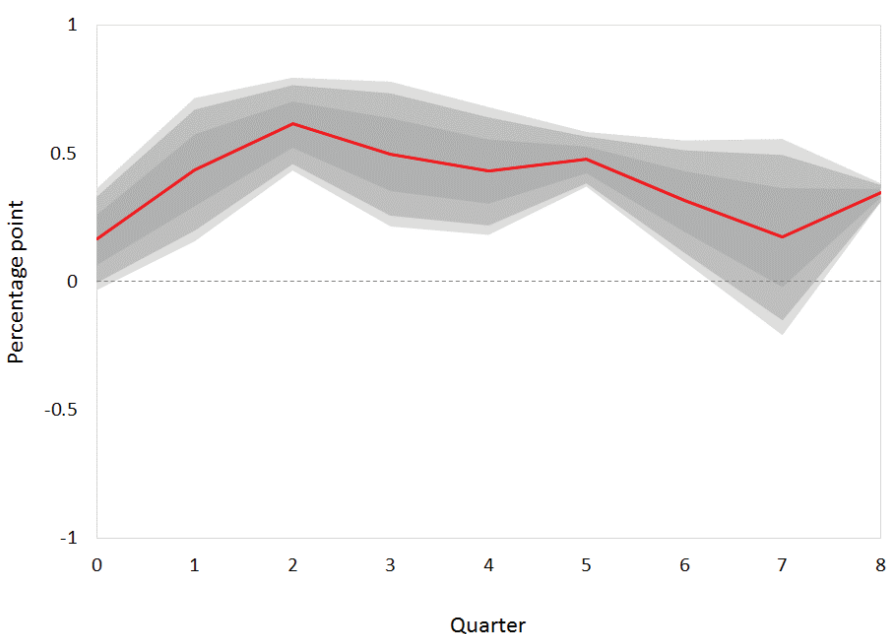

Notes: Dark, medium, and light grey areas show 68, 90, and 95 percent confidence intervals, respectively. Standard errors are clustered at country level.

Figure 11. Cumulative response of GDP to a one-percentage-point one-at-a-time increase in central bank interest rate (IR) and effective constant reserve requirement (ECRR) endogenous shocks

Panel A. Response of GDP to ECRR

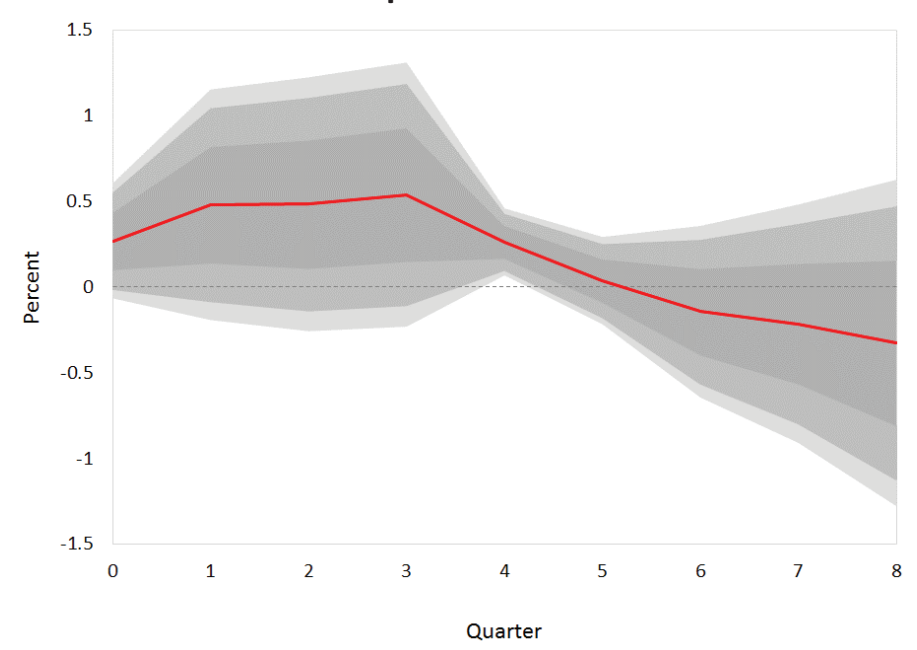

Panel B. Response of GDP to IR

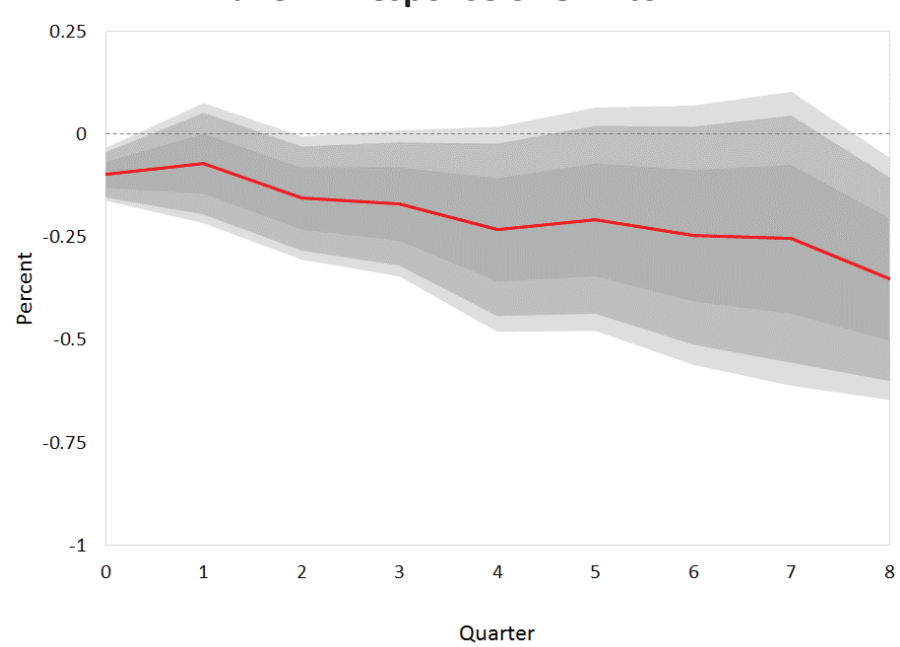

Notes: Dark, medium, and light grey areas show 68, 90, and 95 percent confidence intervals, respectively. Standard errors are clustered at country level. 
Table 1. Categories of changes in legal reserve requirements

Panel A. Total, exogenous, and endogenous changes

\begin{tabular}{lccc}
\hline & total & exogenous & endogenous \\
\hline Argentina (1990:1-2018:1) & 49 & 29 & 20 \\
Brazil (1994:3-2018:2) & 31 & 22 & 9 \\
Uruguay (1990:1-2018:2) & 13 & 11 & 2 \\
Total & 93 & 62 & 31 \\
\hline
\end{tabular}

Panel B. Types of exogenous changes

\begin{tabular}{lccc}
\hline & financial liberalization & liquidity regulation & microprudential \\
\hline Argentina (1990:1-2018:1) & 11 & 7 & 11 \\
Brazil (1994:3-2018:2) & 3 & 12 & 7 \\
Uruguay (1990:1-2018:2) & 0 & 1 & 10 \\
Total & 14 & 20 & 28 \\
\hline
\end{tabular}

Panel C. Types of endogenous changes

\begin{tabular}{lcc}
\hline & good times & bad times \\
\hline Argentina (1990:1-2018:1) & 6 & 14 \\
Brazil (1994:3-2018:2) & 5 & 4 \\
Uruguay (1990:1-2018:2) & 2 & 0 \\
Total & 13 & 18 \\
\hline
\end{tabular}


Table 2. Correlation between changes of legal reserve requirements

Panel A. Argentina: 1990:1-2018:1

\begin{tabular}{|c|c|c|c|c|c|c|c|c|c|}
\hline & 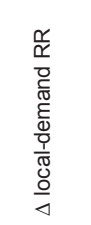 & 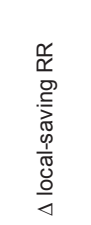 & 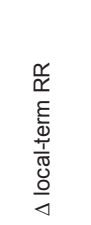 & 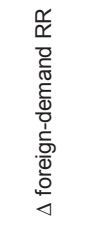 & 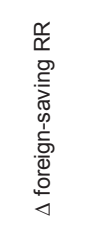 & 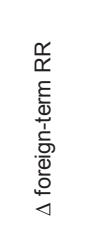 & 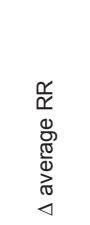 & $\begin{array}{l}\frac{\alpha}{\mathcal{r}} \\
\triangleleft \\
\triangleleft\end{array}$ & $\begin{array}{l}\frac{\alpha}{d N} \\
\frac{d}{W} \\
\triangleleft\end{array}$ \\
\hline$\Delta$ local-demand RR & 1 & & & & & & & & \\
\hline$\Delta$ local-saving RR & $0.52^{\star * *}$ & 1 & & & & & & & \\
\hline$\Delta$ local-term RR & $0.44^{* \star *}$ & $0.43^{\star * *}$ & 1 & & & & & & \\
\hline$\Delta$ foreign-demand RR & $0.68^{\star \star \star}$ & $0.68^{\star \star \star}$ & $0.33^{\star \star \star}$ & 1 & & & & & \\
\hline$\Delta$ foreign-saving $R R$ & $0.42^{\star \star \star}$ & $0.70^{\star \star \star}$ & $0.31^{* * \star}$ & $0.99^{\star \star \star}$ & 1 & & & & \\
\hline$\Delta$ foreign-term $R R$ & $0.30^{\star \star \star}$ & $0.27^{\star \star \star}$ & $0.67^{\star * \star}$ & $0.71^{\star \star \star}$ & $0.68^{* * *}$ & 1 & & & \\
\hline$\Delta$ average $\mathrm{RR}$ & $0.65^{* \star *}$ & $0.77^{\star \star \star}$ & $0.64^{\star \star *}$ & $0.92^{\star \star *}$ & $0.91^{* * *}$ & $0.77^{* * *}$ & 1 & & \\
\hline$\Delta \mathrm{ERR}$ & $0.77^{\star \star \star}$ & $0.61^{\star \star *}$ & $0.69^{* \star \star}$ & $0.74^{\star \star \star}$ & $0.66^{* \star *}$ & $0.67^{* \star \star}$ & $0.85^{\star \star *}$ & 1 & \\
\hline$\Delta \mathrm{ECRR}$ & $0.78^{\star \star \star}$ & $0.80^{\star \star *}$ & $0.70^{\star * \star}$ & $0.82^{* * *}$ & $0.78^{\star \star *}$ & $0.68^{\star \star *}$ & $0.96^{* * *}$ & $0.90^{* * *}$ & 1 \\
\hline
\end{tabular}

Panel B. Brazil: 1994:3-2018:2

\begin{tabular}{|c|c|c|c|c|c|c|}
\hline & 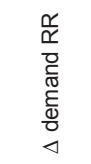 & 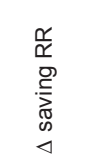 & $\begin{array}{l}\frac{\widetilde{\alpha}}{\widetilde{\alpha}} \\
\xi \\
\Phi \\
\triangleleft\end{array}$ & $\begin{array}{l}\frac{\alpha}{\alpha} \\
\mathbb{d} \\
\frac{\pi}{\sigma} \\
\frac{\pi}{\omega} \\
\stackrel{\sigma}{\sigma} \\
\triangleleft\end{array}$ & $\begin{array}{l}\frac{\alpha}{r} \\
\triangleleft \\
\triangleleft\end{array}$ & $\begin{array}{l}\frac{r}{d 0} \\
\frac{d}{W} \\
\triangleleft\end{array}$ \\
\hline$\Delta$ demand RR & 1 & & & & & \\
\hline$\Delta$ saving $R R$ & $0.29^{\star \star *}$ & 1 & & & & \\
\hline$\Delta$ term RR & $0.22^{* *}$ & $0.30^{* \star *}$ & 1 & & & \\
\hline$\Delta$ average $\mathrm{RR}$ & $0.78^{* * *}$ & $0.62^{* \star *}$ & $0.72^{* * *}$ & 1 & & \\
\hline$\Delta \mathrm{ERR}$ & $0.43^{* * *}$ & $0.62^{* \star \star}$ & 0.16 & $0.51^{* \star *}$ & 1 & \\
\hline$\Delta \mathrm{ECRR}$ & $0.73^{\star \star \star}$ & $0.65^{* * *}$ & $0.75^{\star * *}$ & $0.99^{* * *}$ & $0.52^{* \star *}$ & 1 \\
\hline
\end{tabular}

Panel C. Uruguay: 1990:1-2018:2

\begin{tabular}{|c|c|c|c|c|c|c|c|c|c|}
\hline & 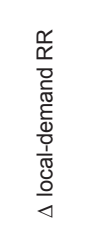 & 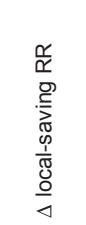 & 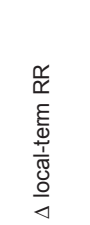 & 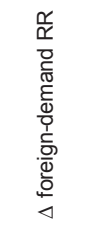 & 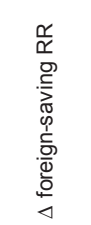 & 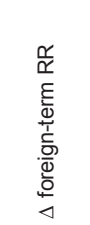 & $\begin{array}{l}\frac{\alpha}{\alpha} \\
\Phi \\
\mathbb{d} \\
\frac{\tilde{\sigma}}{\omega} \\
\frac{\pi}{\pi} \\
\triangleleft\end{array}$ & $\begin{array}{l}\frac{\alpha}{\widetilde{r}} \\
\underset{\triangleleft}{\Psi}\end{array}$ & 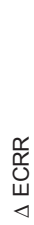 \\
\hline$\Delta$ local-demand RR & 1 & & & & & & & & \\
\hline$\Delta$ local-saving $R R$ & $0.86^{\star \star *}$ & 1 & & & & & & & \\
\hline$\Delta$ local-term RR & $0.57^{* * *}$ & $0.70^{* * *}$ & 1 & & & & & & \\
\hline$\Delta$ foreign-demand RR & $0.42^{* \star *}$ & 0.01 & 0.01 & 1 & & & & & \\
\hline$\Delta$ foreign-saving $R R$ & $0.42^{* \star *}$ & 0.01 & 0.01 & 1 & 1 & & & & \\
\hline$\Delta$ foreign-term $R R$ & $0.25^{* \star *}$ & -0.03 & -0.01 & $0.88^{\star \star \star}$ & $0.88^{\star \star *}$ & 1 & & & \\
\hline$\Delta$ average $R R$ & $0.86^{* * *}$ & $0.63^{* * *}$ & $0.56^{* * *}$ & $0.76^{\star * *}$ & $0.76^{\star * *}$ & $0.66^{* * *}$ & 1 & & \\
\hline$\Delta \mathrm{ERR}$ & $0.58^{* * *}$ & 0.18 & 0.19 & $0.96^{* * *}$ & $0.96^{* \star *}$ & $0.83^{* \star *}$ & $0.89^{* * *}$ & 1 & \\
\hline$\Delta$ ECRR & $0.54^{* * *}$ & 0.15 & 0.12 & $0.99^{* * *}$ & $0.99^{* * *}$ & $0.88^{* * *}$ & $0.85^{* * *}$ & $0.99^{* * *}$ & 1 \\
\hline
\end{tabular}

Notes: RR, ERR, and ECRR stand for legal reserve requirement, effective legal reserve requirement, and effective constant legal reserve requirement, respectively. See Section 2.3 for details regarding the construction of ERR and ECRR. 